\title{
Análise musical: a Idade Média em Carmina Burana de Carl Orff
}

\section{B runo A Imeida C osta Penna}

L icenciatura em M úsica, F aculdade Santa C ecília

Pós $\mathrm{G}$ raduação em $\mathrm{E}$ ducação $\mathrm{M}$ usical, $\mathrm{F}$ aculdade $\mathrm{C}$ ampos $\mathrm{E}$ líseos. 


\section{Resumo}

C armina B urana é uma obra musical até hoje interpretada por várias orquestras e coros, e também apreciada por vários músicos e estudantes de música. Entender quais ferramentas da I dade M édia se faz presente dentro dessa obra moderna é indispensável para compreender a composição de Carl O rff. Com o objetivo de esclarecer essa questão, foi realizada uma análise de caráter explicativo abordando contexto histórico e musical. Por meio de pesquisa em livros, documentos, artigos e sites, além da referência gráfica da partitura de C armina Burana C antiones Profanae, ed 2877, da editora SottE hamc, foi estruturada uma, dentre outras possibilidades, interpretação analítica desta obra. E ste artigo pretende contribuir musicologicamente com análise musical além de informações documentais.

Palavras-chave: C armina Burana. A nálise M usical. I dade M édia. C arl O rff.

\section{Abstract}

Carmina Burana is a musical work until the present time performed by various orchestras and choirs, and also enjoyed by various musicians and music students. Understanding what tools of the $\mathrm{M}$ iddle A ge are present within this modern work is indispensable to understand this composition of $\mathrm{C}$ arl $\mathrm{O}$ rff. In order to clarify this question, was done an analysis with explanatory character using history and musical context. D ue to this fact, using searches in books, documents, articles and websites, based on the score of $C$ armina B urana $C$ antiones Profanae, ed 2877, of the Shott- $E$ amc publishing house, it was structed one, among others possibilities, analytic interpretation about this work of art. This article want to contribute to musical form with musical analyze beside documents information.

Keywords: C armina B urana. M usical A nalysis. M iddle A ge. C arl O rff. 


\section{Introdução}

A questão "Quais os fragmentos e ferramentas da Idade Média estão presentes em Carmina Burana de Carl Orff"? Preocupação central do artigo, requer pesquisa sobre o compositor, a obra e uma análise da última enfocando estilo da música medieval.

$\mathrm{N}$ a pesquisa sobre o compositor $\mathrm{C}$ arl O rff e o contexto de $\mathrm{C}$ armina Burana terá como base autores como G oulart (2000); Colarusso (2013); Galindo (2013); Coggiola (2015); e L ukacs (1980).

A base da análise e a compreensão de C armina Burana com a idade média serão as teorias de Júnior (2001); G rout e Palisca (1994); C opland (2011); B ennett (1986); M ed (1996); Sadie (1994), e a partitura a ser nalisada é a C armina B urana C antiones Profanae, ed 2877, da editora Shott-E amc.

Estruturalmente, esse trabalho está divido em três capítulos; no primeiro, compreende o contexto que $\mathrm{C}$ arl 0 rff compôs $\mathrm{C}$ armina Burana e o cenário perturbador que enfrentou da Alemanha Nazista; no segundo, a relação de Carmina Burana com a Idade Média e com estilo de composição medieval; e o terceiro, a análise musical enfocando procedimentos composicionais medievais na obra.

\section{O compositor Carl Orff e o nazismo}

Carl Orff foi um compositor alemão, nascido na cidade de $M$ unique (18951982), "começou a estudar piano aos cinco anos sob orientação de sua mãe. $\mathrm{N}$ a escola, interessou-se vivamente pelas línguas clássicas, poesia e literatura” (Goulart, 2000, p. 10). D o interesse do compositor em unir música, poesia e literatura originou C armina B urana, composta e estreada durante o regime nazista, sendo sua única obra artística criada neste período, a permanecer conhecida, como explica o maestro $\mathrm{O}$ svaldo C olarusso:

E la foi escrita em 1935 e estreada em junho de 1937 em Frankfurt. 0 bra que a princípio não agradou muito aos líderes nazistas mais à frente foi glorificada por eles, e sua estreia em M ilão em 1942 foi saudada como uma gloriosa junção cultural dos dois países fascistas. $V$ ale a pena lembrar que esta obra é a única produção artística da Alemanha nazista a permanecer conhecida sendo que nem os pintores, nem os compositores e nem os escritores que escreveram seguindo as regras do partido são hoje lembrados. (C O LA RUSSO, p. 1, 2013) 
Carmina Burana, apesar de hoje ser uma obra apreciada, a princípio não teve sucesso, vindo a ser reconhecida sete anos após sua criação na Itália. Foi concebida em cenário político extremo "no ano de 1935, mesmo ano da promulgação da lei de Nuremberg em que restou configurada a subcondição humana imposta ao povo judeu, definitivamente estigmatizado e relegado a uma subespécie pelos nazistas" (GALINDO, 2013 , p. 2) tendo C arl O rff presenciado a perseguição que a A lemanha impunha contra os judeus.

No ano de estreia da obra a perseguição só aumentava e O rff encarou cenário perturbador, que com certeza intimidava qualquer artista, podendo fazê-lo desistir de expor sua criação:

A política antijudaica se acelerou no final do ano de 1937 e durante todo o ano de 1938, momento em que o antigo lema: "política de arianizaçấo" voltou a ser palco aos olhos do E stado que não mais permitia a presença de judeus em empresas e negócios diversos. Sem falar que no início de 1938 a campanha econômica antijudaica fez com que decretos e leis fossem editadas para impedir toda a possibilidade econômica dos judeus na A lemanha, obrigando- os a deixar seus negócios, liquidar suas empresas e entregar todos os seus bens as autoridades estatais, uma vez que iriam sair definitivamente da A lemanha. (G A L IN D O , 2013, p. 4)

$\mathrm{N}$ esse momento, a obra não foi bem aceita pelo estado nazista, no entanto 0 rff conseguiu Itália em pleno fervor da Segunda G uerra M undial:

A "loucura nazista" revelava-se assim, também, militarmente suicida. No final da guerra, o mais importante era levar a cabo o extermínio dos judeus. D epois de diversos ensaios, como a perseguição e extermínio dos doentes mentais alemães durante vários anos, a solução final, com 0 emprego de câmaras de gás, foi finalmente posta em operação em 1942. (COGGIOLA, 2015 p. 59)

E m 1942 a guerra começava a chegar a seus capítulos finais, e com isso a A lemanha Nazista chegava ao extremo, ao ponto culminante de seu terror, a câmera de gás, exterminando assim milhões de judeus.

A princípio, $\mathrm{H}$ itler objetivava perseguir e expulsar os judeus da A lemanha, mas essa perseguição tomou caminhos tenebrosos e o extermino dos Judeus se tornou uma prática sistêmica:

$\mathrm{O}$ objetivo original de $\mathrm{H}$ itler era expulsar, não exterminar; forçar todos os judeus a abandonar a A lemanha, não matá-los... o tratamento dado por 
$\mathrm{H}$ itler aos judeus era parte integrante de sua concepção de luta mundial. Foi em virtude da guerra que a política alemã estava se voltando, gradativamente, na direção de uma 'solução mais ou menos final'... Em janeiro de 1942, a exterminação sistemática dos judeus de toda a E uropa tornou- se a política oficial alemã. (L UKAC S, 1980, p. 471-475)

Interessante perceber que $\mathrm{C}$ arl $\mathrm{O}$ rff não conseguiu o sucesso de sua obra principal no embrião da guerra ou quando a política da A lemanha era só de perseguição, mas quando a guerra e a política alemã de extermínio chegavam ao seu extremo.

Sem sombra de dúvidas, nada pode tirar o brilhantismo musical contido nessa obra, afinal, houve necessidade de persistência para alcançar reconhecimento. $N$ ão se pode esquecer que $C$ armina Burana é a única obra artística que é reconhecidamente produzida neste período perturbador, e que sobreviveu a queda da A lemanha $\mathrm{N}$ azista.

\section{A Idade Média em Carmina Burana}

0 fato de poemas musicados serem medievais justifica um breve estudo de contexto histórico. Vale esclarecer que os autores dos textos de Carmina Burana são goliardos, personagens misteriosos que segundo Júnior (2001, p.153) eram "socialmente clérigos, ainda que não saibamos se eram todos estudantes pobres e errantes, ou se entre eles havia elementos bem colocados na hierarquia do clero, das cortes e das universidades" Já Palisca assim os definia:

Os goliardos - nome derivado de um patrono provavelmente mítico, o bispo Golias - eram estudantes ou clérigos errantes que migravam de escola em escola nos tempos que precederam a fundação das grandes universidades sedentárias. A sua vida vagabunda, mal vista pelas pessoas respeitáveis, era celebrada nas suas canções, de que foram feitas numerosas colectâneas manuscritas. $0 \mathrm{~s}$ temas dos textos integram-se quase sempre na eterna trindade de interesses dos jovens do sexo masculino: vinho, mulheres e sátira. 0 tratamento que lhe e dado, umas vezes, é delicado, outras, não; o espírito é francamente mordaz e informal, como se torna bem perceptível ao ouvirmos algumas das versões musicais modernas dos Carmina burana de Carl Orff. (GROUT; PALISCA, 1994, p.83-84)

Os temas de Carmina Burana são justamente os designados pelos goliardos: amores, vinhos, mulheres, jogo, entre outros. De temas vulgares eles "produziam uma 
poesia erudita em latim e popular na versificação (rítmica e rimada)" (JÚNIOR, 2001, p. 153), mais uma vez soa contraditório, no entanto C arl O rff soube explorar a tensão entre erudição e o popularesco, fato que toma a obra encantadora.

O s goliardos representavam, personagens medievais e toda a ironia que se rompia contra a igreja, os cavaleiros e camponeses como explica o historiador H ilário Franco Júnior:

Suas ironias pouco sutis contra a I greja levaram o concilio de Salzburgo, em fins do século XIII, a considerá-los "blasfemos que se proclamam clérigos para escárnio do clero". Na verdade, eles também reservavam suas farpas contra os cavaleiros e os camponeses. Por isso já foi dito, não sem certo exagero, que, "mais que revolucionários, os goliardos sẫo antes anarquistas". Eles representavam, à sua maneira, o sentimento nostálgico de uma I dade de $\mathrm{O}$ uro, sentimento que se desenvolvia à medida que avançavam as transformações econômicas e políticas da época. U m dos temas caros a eles era o da Roda da Fortuna, cíclica, oposta ao conceito temporal linear e progressista típico da visão histórica cristã. (JÚ N IOR, 2001, p. 153)

Um dos temas principais em Carmina Burana é o da roda da fortuna, interagindo com os ideais medievais dos goliardos, estruturando o clima irônico pertinente.

A estrutura da obra de Carl O rff se deve aos poemas dos goliardos, que foram encontrados num mosteiro, e o próprio nome da obra de O rff leva o nome desse

mosteiro em latim. 0 compositor selecionou dentre 300 poemas alguns e os ordenou em temas (amor, bebidas e mulheres), e construiu a trama de uma brilhante obra:

0 rff fez uma seleção dentre os mais de 300 textos escritos na idade média encontrados num mosteiro da B aviera. 0 nome $C$ armina B urana significa em latim Canções do mosteiro Benediktbeuern. 0 rff escolheu apenas 22 poemas e os agrupou em assunto para construir um tipo de enredo. N um prólogo, que será o epílogo também, o texto fala dos caprichos da roda da fortuna. A primeira parte fala do despertar da natureza e do amor na primavera, sendo que na segunda parte, com um clima mais sombrio, ele fala de uma noite de excessos gastronômicos e alcoólicos numa taberna. A terceira parte fala de um amor que se torna mais vulgar, mostrando que tudo pode ser modificado pelos caprichos do destino. (COLARUSSO, 2013, p. 1)

Carmina Burana é uma cantata cênica constituída por um ciclo de pequenas peças musicais, com os textos do mosteiro da Baviera. 0 tema roda da fortuna é apresentado logo nos dois primeiros movimentos na introdução da obra, o Fortuna I mperatrix M undi. 
0 amor pela primavera é tema da primeira parte da obra: Primo V ere. L ogo em seguida, 0 ode à vida noturna e aos prazeres do álcool, parte é cantada somente por vozes masculinas; a segunda parte é In Taberna; e para finalizar, a terceira parte está o Courd'Amours que trata 0 amor vulgar e a luxúria. A o final do ciclo, se repete o movimento 0 Fortuna para finalizar essa brilhante obra de $\mathrm{C}$ arl $\mathrm{O}$ rff.

Carl Orff estruturou suas técnicas composicionais de forma muito singular, estruturando assim, um estilo muito próprio na construção melódica, harmônica, contrapontística, textural, rítmica e formal.

Carl O rff se inspira no cantochão medieval para compor sua obra de tratamento obviamente medieval. A ssim como o cantochão, as melodias de C armina B urana são feitas, na maioria das vezes, por grau conjunto e se mantém dentro de uma oitava e com inspirações modais. No cantochão "o único acidente legitimamente usado na notação do cantochão é o Sib.” (GROUT; PALISCA, 1994, p.79), podendo ser esse o motivo que o compositor utilizou na obra, no âmbito tonal, a tonalidade de fá maior e ré menor.A estrutura melódica que O rff estrutura é próxima ao arco descrito por GROUT; PALISCA , 1994, p. 61: N a maioria dos casos, a linha melódica tem a forma de um arco: começa em baixo, eleva-se até um ponto mais alto, onde permanece por algum tempo, e volta a descer no final da frase. Essa configuração simples e natural é observável numa grande variedade de combinações sutis; por exemplo, a curva melódica pode abranger duas ou mais frases ou incluir curvas menores.

U ma classificação é em base no canto, quando os coros catam alternadamente é classificado de antifonal, e, quando um solista alterna com um coro, é classificado de responsórial, e ainda pode ser classificado como "directo (sem alternância)." (GROUT; PALISCA, 1994, p. 60).

A parte rítmica da obra de 0 rff se assemelha ao cantochão pela inconstância rítmica, por esse motivo talvez, com a inspiração no cantochão, 0 rff muda tanto a fórmula de compasso dentro de um movimento. O utra ferramenta para remeter o ritmo do cantochão é o rubato "(It., roubado) Diz-se 0 andamento alargado além daquele matematicamente disponível; assim, retardado, prolongado ou ampliado." (SADIE, 1994, p. 805) e também possui uma variedade muito grande do andamento dentro dos movimentos de Carmina Burana. 0 ritmo era impreciso, instável e prosódica, ou seja, seguia o ritmo das palavras do poemas. A notação das durações era bastante rudimentar, 0 cantochão usava "a notação numa pauta, com neumas, era, no entanto, ainda bastante imperfeita; representava a altura das notas, mas não indicava a sua duração relativa." (GROUT; PA LISCA , 1994, p.82), talvez, esse seja um dos motivos de C arl O rff utilizar 
figuras rítmicas antigas em algumas partes da obra, isso por causa da anotação medieval, como explica Bohumil M ed:

A ntigamente eram palavras que indicavam, mais ou menos, o tempo de duração de cada nota. No princípio do século XIII surgiram as figuras mensurais para determinar a duração dos sons. As mais antigas eram a M áxima, a Longa, a Breve, a Semibreve, a M ínima e a Semínima. (M E D, 1996, p.20)

Já a textura, em algumas partes do coro, é monofônica como a do canto gregoriano. Em outras partes, ela segue como a transformação da textura na Idade Média "o organum, na sua primeira fase - em que a voz suplementar se limita a duplicar a original num intervalo fixo". (GROUT; PALISCA, 1994, p.99), isso acontece na maioria do Carmina Burana, as vozes duplicam em um único intervalo.

As vozes no período medieval se chamavam vox principalise e vox organalis. Com 0 tempo a vox organalis que duplicava as vox principalis ganhava mais liberdade, podendo agora não somente ter um intervalo fixo e sim fazer outros intervalos e além de movimento contrário:

$\mathrm{N} o$ início da I dade M édia a vox organalis geralmente ficava abaixo da vox principalise o conceito baseou-se em 4ạs e $5 \underline{a}$ s paralelas. Sob a influência da necessidade teórica de se evitar o trítono, e as exigências do sistema de tetracordes, outros intervalos tornaram-se aceitáveis; no séc.XIII o movimento paralelo em terças e o movimento contrário eram importantes, e a vox organalis desfrutou de maior liberdade de movimento, acabando por se estabelecer como a voz mais aguda. (SA DIE, 1994, p.679)

0 tratamento das vozes em Carmina Burana foi semelhante, algumas partes fazendo em intervalos fixos como um organum paralelo, e outras fazendo movimentos contrários, como um organum livre.

A lém de classificar o canto gragoriano através do canto, como antifonal, responsorial ou directo, pode ser também como é cantado cada sílaba, a terceira fase de construção organal é a melismática onde:

“(...). Os cantos em que a maioria ou a totalidade das sílabas correspondem cada uma à respectiva nota designam-se por silábicos; os que se caracterizam por longas passagens melódicas sobre uma única sílaba designam-se por melismáticos. A distinção nem sempre é nítida, uma vez que as peças predominantemente melismáticas costumam incluir alguns trechos ou frases silábicas e muitas peças quase inteiramente 
silábicas têm, por vezes, breves melismas de quatro ou cinco notas sobre algumas sílabas. Este tipo de cantochão recebe, por vezes, nome de neumático." (GROUT; PALISCA, 1994, p.60)

0 melisma foi mais uma evolução da música medieval, assim surgindo 0 organum melismático, o interessante é que, como explica Bennett (1986, p. 14-15), no século XII, a voz principal passou a ser chamada de tenor, palavra que vem do latim tenere, que significa manter, pois essa voz ficava longamente sustentada, para a voz mais alta se movimentar em melismas, só que, esses valores começaram a ficar extremamente longos, o que levou os tenores da catedral de $\mathrm{N}$ otre- $\mathrm{D}$ ame a serem substituídos ou ajudados por instrumentos da época, como o órgão.

A A rs N ova, última fase da música medieval, trouxe novas maneiras de tratar as melodias das músicas, técnicas novas como, por exemplo, o isorritmo (ritmo-patrão), uma sequência rítmica que fica se repetindo por toda obra. (BE N N ETT, 1986, p. 20) C arl 0 rff utilizou essa repetição em quase toda obra. A lém do isorritmo, na A rs N ova apareceu outra técnica utilizada pelos compositores da I dade M édia chamada hoqueto:

O utra técnica muito apreciada pelos compositores medievais e percebida com grande clareza em sua música é o hoqueto(palavra que poderia perfeitamente traduzir-se por soluço). A melodia apresenta-se partida, formando frases curtas, chegando mesmo a ter pausas separando as notas. (BE N NETT, 1986, p. 21)

A técnica é interessante pois pode ter sido inspiração numa frase de um movimento. E por último, uma técnica de harmonia, que é chamado de fauxboudon "funcionava como um simples meio harmonizar um cantochão" (SADIE, 1994, p. 315), assim o fauxboudon é "uma cadeia de acordes construídos com intervalos de terça e sextas. As terças são também utilizadas nos intervalos melódicos da voz superior, quase sempre acompanhando as notas de acordes subjacentes" (BENNETT, 1986, p. 21) a técnica que O rff utiliza na harmonização de sua obra, se não na totalidade, em al gumas partes, pois é a técnica que harmoniza o canto gregoriano.

\section{Análise Musical: Carmina Burana}

No primeiro movimento do $\mathrm{F}$ ortuna Imperatrix M undi, chamada $0 \mathrm{~F}$ ortuna, tem a forma de canto neumático, prevalecendo a forma silábica; o compositor compôs na 
tonalidade de ré menor, muito se deve pelo sib na armadura de clave, e por ele ser o único acidente usado no cantochão, a introdução que possui quatro compassos foi escrita para seis vozes (baixo, tenor 1 , tenor 2 , contralto, soprano 1, soprano 2), porém, tem apenas três linhas melódicas, onde o contralto duplica em intervalo fixo de oitava a linha melódica do baixo, a soprano 1 duplica o tenor 1 , e soprano 2 com tenor 2, onde essas três linhas melódicas tem movimentos livres porém dependentes no ritmo:

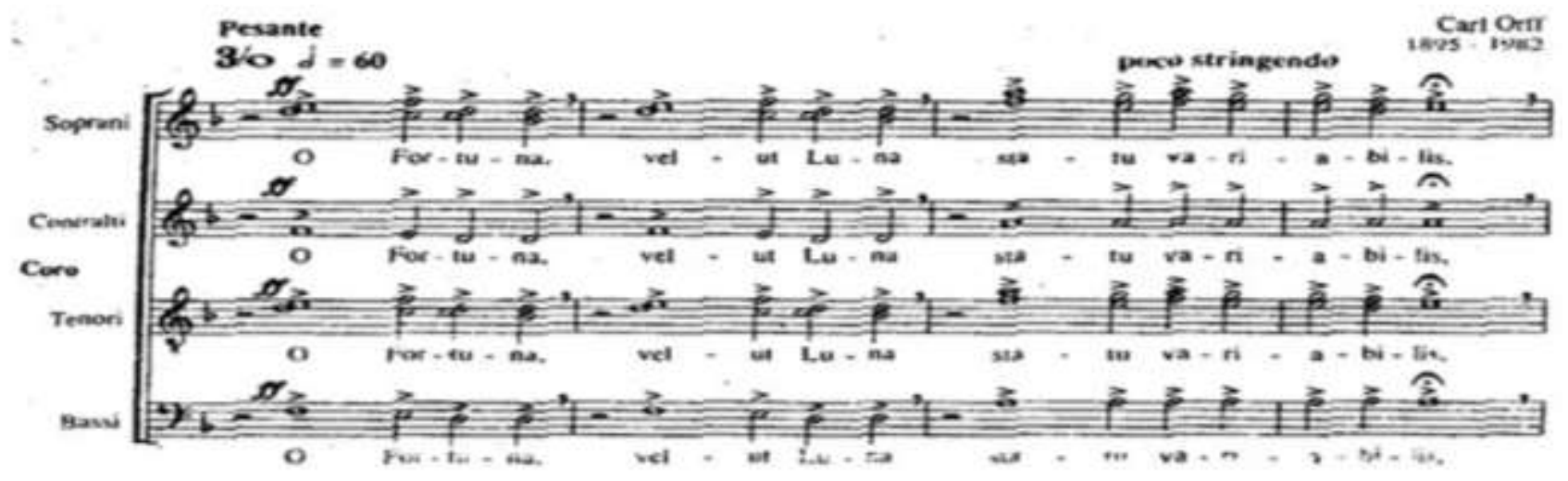

D escrição: Introdução - 0 Fortuna.

Fonte: C armina Burana, C arl O rff E D 2877 p. 5.

O rff começou o movimento com fórmula de compasso 3/1, logo depois da introdução no segundo sistema muda para 3/2, e a música passa a ser para quatro vozes (baixo, tenor, contralto e soprano), todavia, como no cantochão só há uma única linha melódica, todas as vozes se duplicam em oitava, isso tudo com o mesmo ritmo e se desenvolvendo predominantemente em graus conjuntos. $C$ arl 0 rff compôs motivo de dois compassos, que se repete por quase toda a música, e uma frase com oito compassos, que só muda a altura das notas, mas a classificação dos intervalos e o ritmo da frase continuam os mesmos, características do isorritmo:

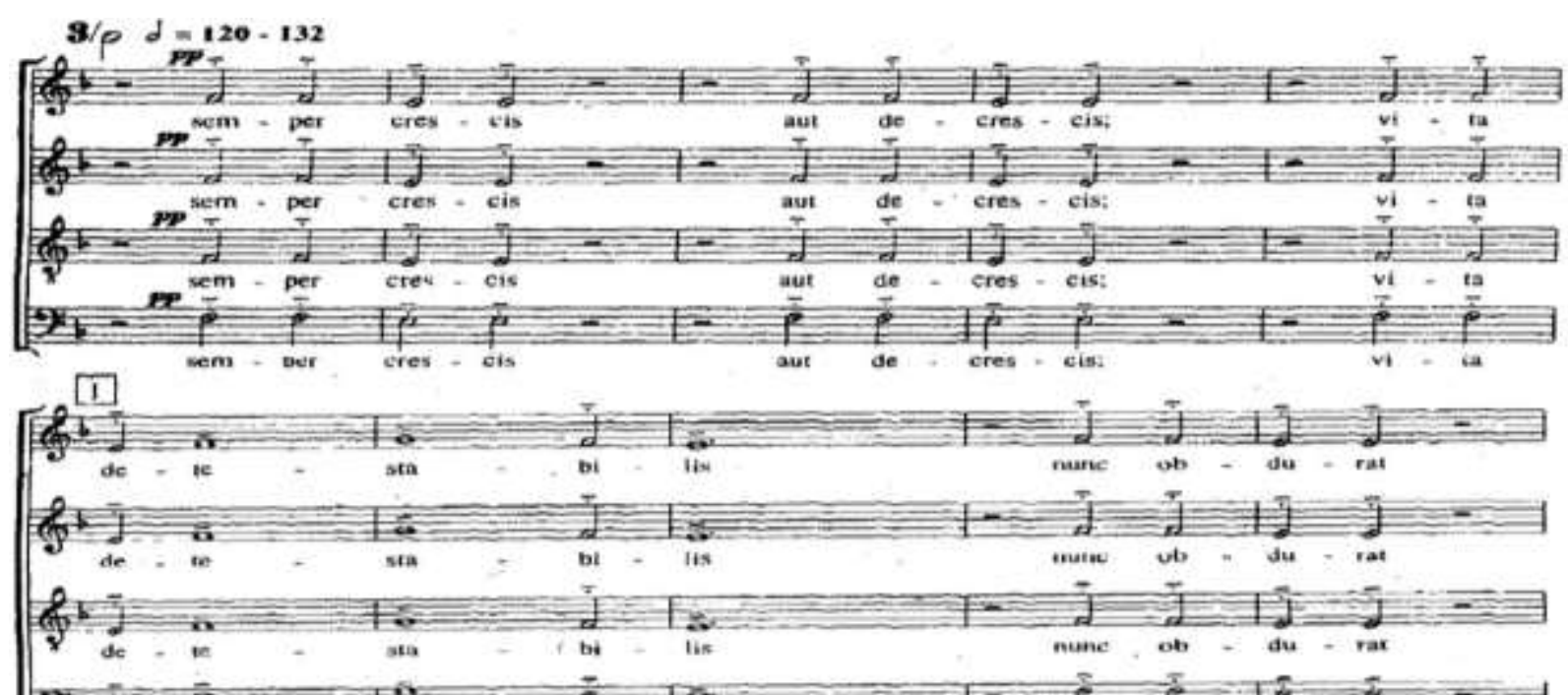


A té a última frase da música, ela foi totalmente silábica, na nona parte do movimento, na última frase acontece o meslisma (no segundo compasso da imagem abaixo), 0 baixo e 0 contralto se mantêm na nota lá, enquanto as outras vozes fazem breves melismas; no primeiro, são cinco notas em uma única silaba; e no segundo, (quarto compasso da imagem abaixo), apenas duas notas, finalizando todos na nota ré, sustentada até o final da música:

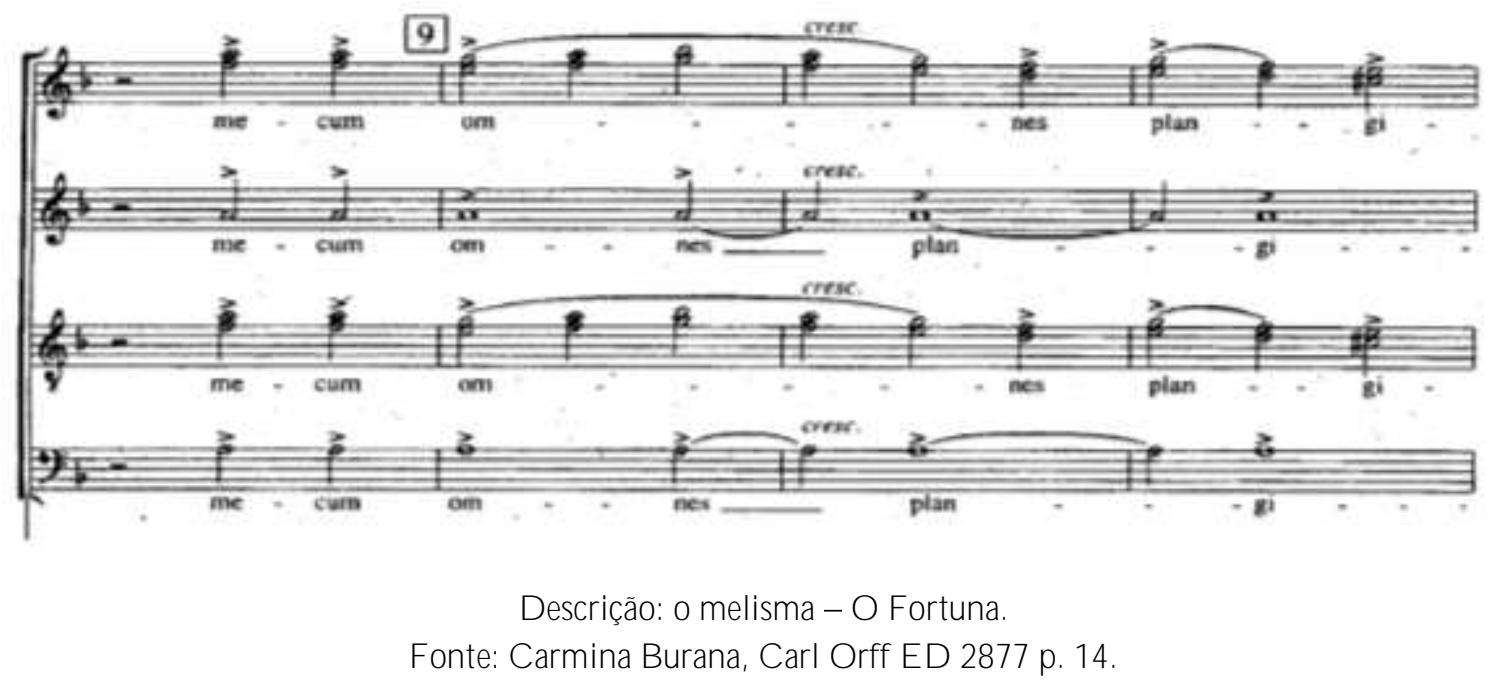

No F ortune plango vulnera continua em ré menor, há movimento neumático e em responsório, muito interessante, pois ele fez uma frase de quatro compassos para solo de baixo em que os três primeiros compassos é $4 / 2$, e no último compasso da frase é $1 / 2$, essa frase é repetida novamente, porém com outro texto, e 0 rff pode ter se inspirado nos organa de $\mathrm{N}$ otre- $\mathrm{D}$ ame, as longas notas que $\mathrm{o}$ tenor sustentava e que acabou substituído por instrumentos; nessa parte, a orquestra sustenta uma única nota, o ré, enquanto o baixo desenvolve uma frase, que transmite a sensação do modo dórico, com a maioria dos intervalos em graus conjuntos e com um âmbito de quinta (rélá):

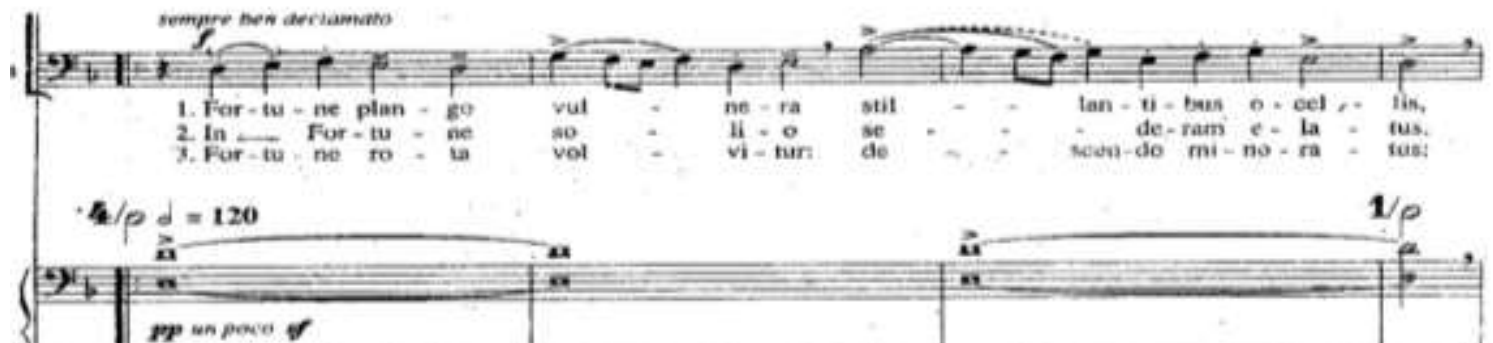


D escrição: $F$ rase do baixo - F ortune plango vulnera.

Fonte: C armina Burana, C arl O rff ED 2877 p. 15.

D epois começa 0 responsório, o coro entra em 4/2, primeiramente com baixo e tenor em que fazem paralelo em terça, desenvolvendo somente por grau conjunto: 


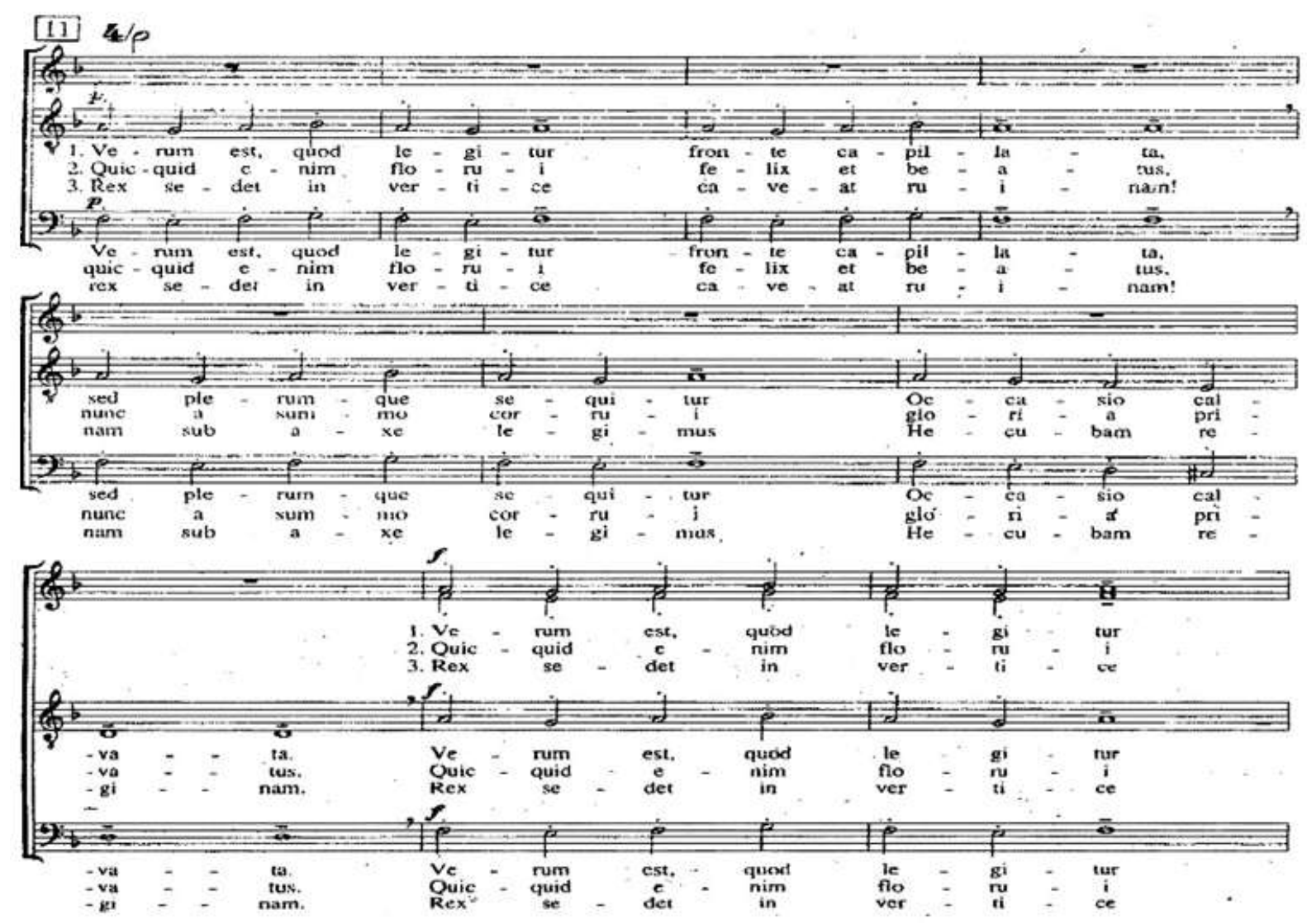

D escrição: F rase - F ortune plango vulnera.

Fonte: Carmina Burana, C arl O rff E D 2877 p. 16-17.

D epois de cantar a frase de oito compassos (duas semifrases de quatro compassos), repete a mesma frase com contralto duplicando em oitava o baixo, e a soprano o tenor; e no final da música, quando acaba a parte do coro, muda para 2/2, e com o ritornelo repete tudo mais duas vezes com textos diferentes.

A gora começa a primeira parte (compasso incial e final da parte): Primo Vere, com o movimento Veris leta facies que está na tonalidade de lá menor, um movimento para coro piccolo, com a forma de canto em antifônico, pois um coro formado por baixo e contralto fica alternando com um coro formado por tenor e soprano. Também neumática, com textura predominantemente melismática, com breves melismas de duas notas, 0 movimento começa em 6/4 (corresponde a duas mínimas pontuadas), e dois compassos, depois muda para 9/4 (corresponde a três mínimas pontuadas), fazendo essa introdução, 0 movimento vai para $1 / 2$ e, no próximo compasso, vai para 6/4 novamente, mas que dura apenas um compasso também, e em seguida vem uma frase em um compasso de 24/4 (corresponde a oito mínimas pontuadas). E ssa frase possui apenas uma linha melódica em que contralto duplica em oitava o baixo e tem a mesma inspiração vinda de $\mathrm{N}$ otre-D ame, pois a orquestra sustenta longas notas enquanto as vozes do coro se desenvolve fazendo breves melismas: 



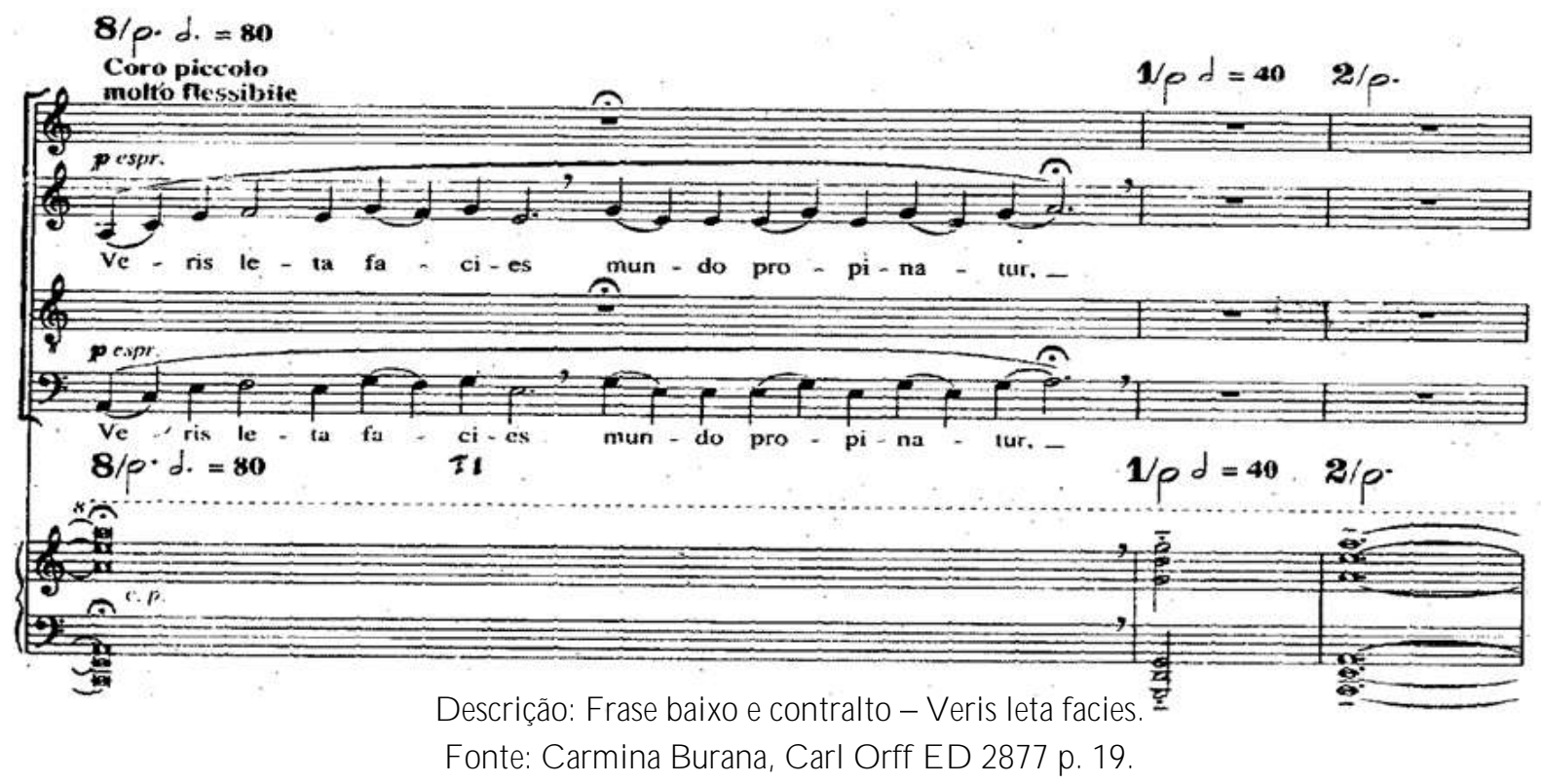

Repete essa estrutura uma vez com outro texto, e seguida da frase do tenor e soprano, também com apenas uma linha melódica, com quatro compassos de 12/4 (corresponde a quatro mínimas pontuadas), dois compassos de 6/4, um compasso de 9/4 e finaliza com um compasso em 6/4; essa é a estrutura rítmica dessa música que se repete mais três vezes no decorrer do movimento, desenvolvendo o texto:

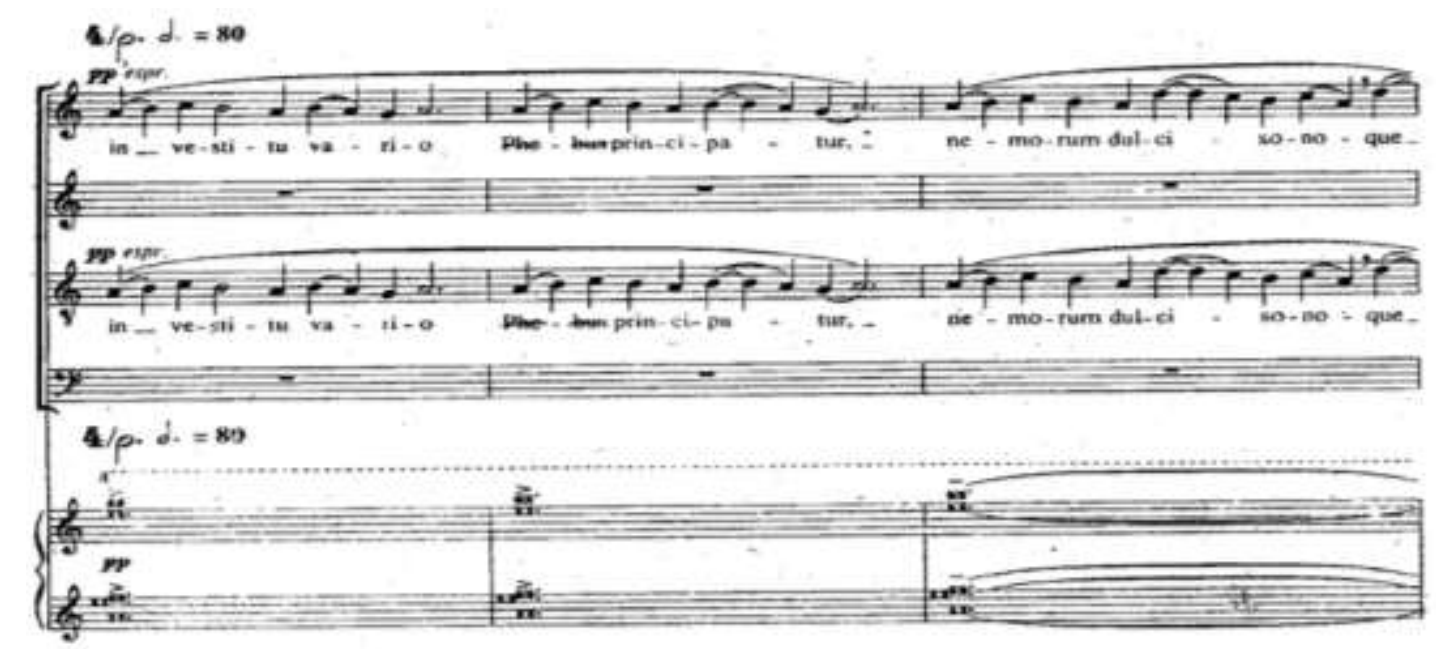

D escrição: F rase baixo e contralto - V eris leta facies.

Fonte: Carmina Burana, C arl O rff E D 2877 p. 19.

No O mnia sol temperat um movimento para barítono solo, a tonalidade é ré menor, a música silábica e directo, com a melodia movida majoritariamente por grau conjunto, se servindo de um único salto no final de um compasso para começar outro. E ssa 
peça possui duas frases melódicas de quatro compassos cada uma, iniciando por anacruse, repetida três vezes. A primeira tem extensão de quinta (ré-lá), e a segunda também (solré), porém a nota final é lá, dando a sensação do modo frígio. $\mathrm{N}$ a harmonia, ele utiliza, mais uma vez, notas extremamente longas enquanto o barítono desenvolve a melodia. $\mathrm{Na}$ parte rítmica, C arl 0 rff utiliza outra ferramenta para se produzir o ritmo inconstante do canto gregoriano, a fórmula de compasso é uma só a música inteira: $2 / 2$, mas ele se serve de rubato:

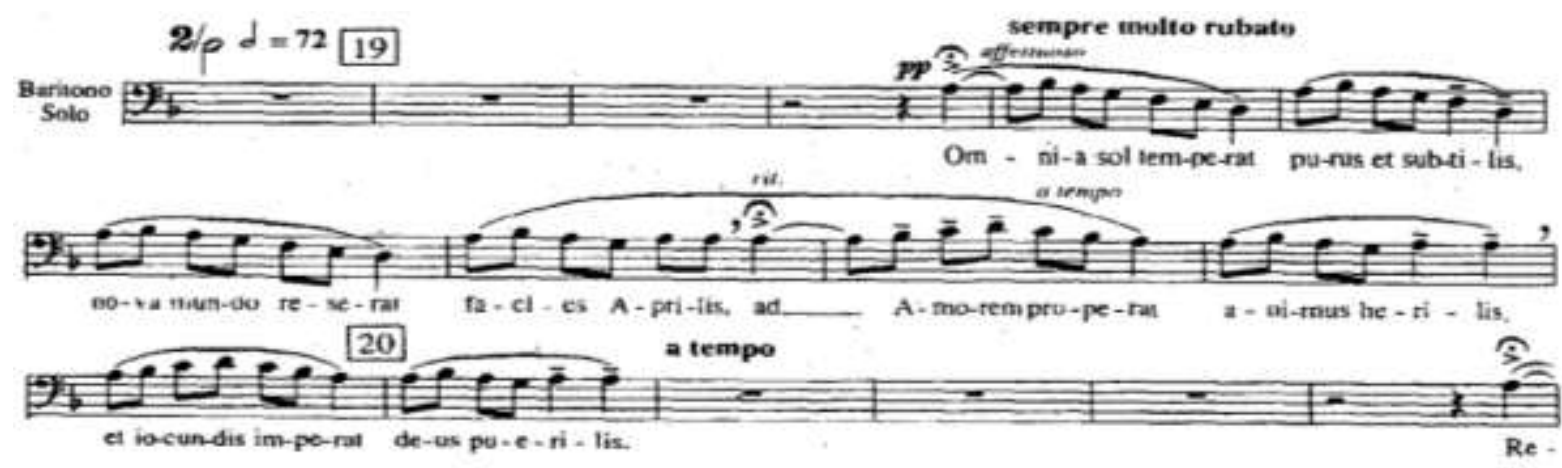

D escrição: Frase - 0 minia sol temperat.

Fonte: C armina Burana, C arl O rff ED 2877 p. 26.

O Acce gratum está na tonalidade de Fá M aior, é um movimento directo e neumático, mas pode ser divido em três partes: a primeira parte é totalmente silábica, tem um compasso de introdução feita pelo tenor, depois uma frase de quatro compassos de três vozes (baixo, barítono e tenor), depois essa frase é repetida no contralto duplicando em oitava o baixo, mezzo duplicando 0 barítono, e a soprano o tenor. N essa parte, as melodias se fazem de modo mais livre, contudo ritmicamente são dependentes com a presença do isoritmo, pois a ideia rítmica do segundo compasso é repetida várias vezes em todas as vozes, provavelmente inspirada no fauxboudon:

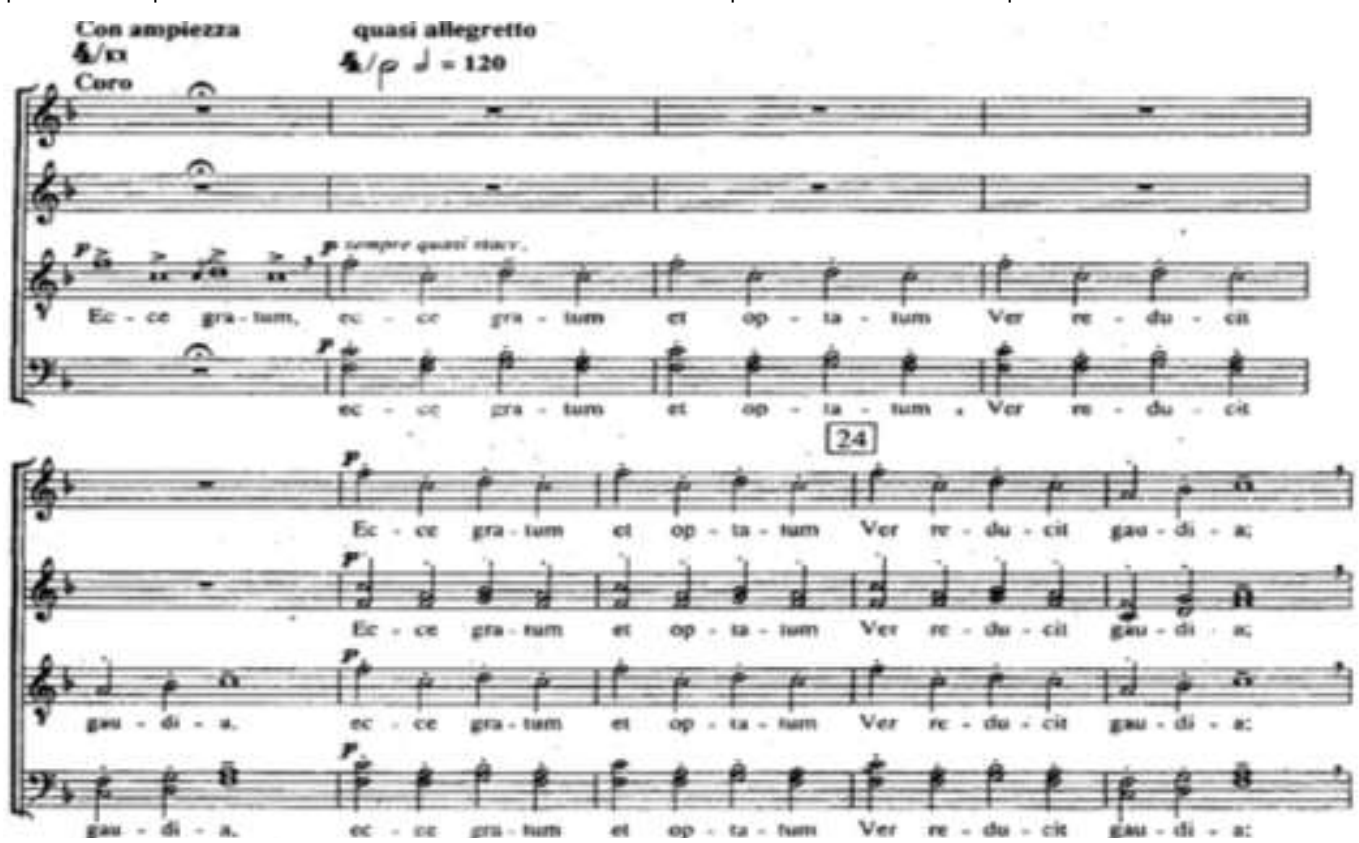


A segunda parte se constitui em uma única melodia com a extensão de uma oitava (ré-ré) em quatro compassos, é evidentemente melismática, em que cada silaba do texto é cantada por duas notas, e todas as vozes se duplicam em oitava.

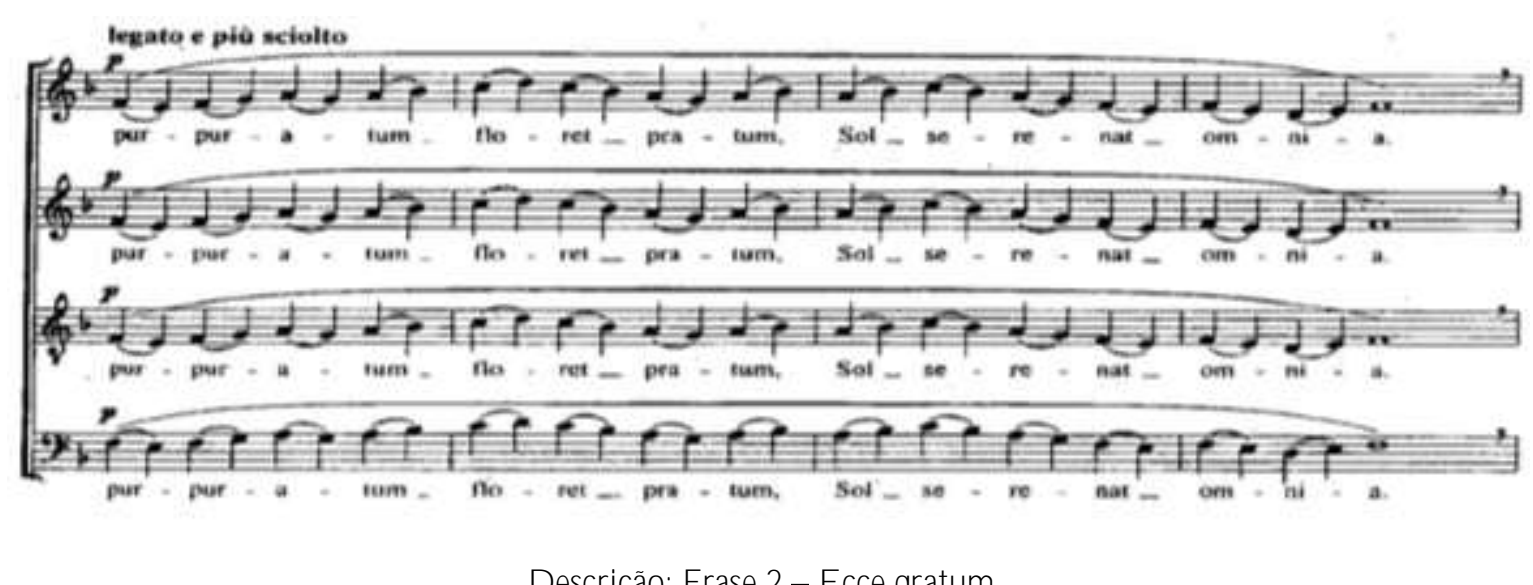

D escrição: Frase 2 - E cce gratum.

Fonte: C armina Burana, C arl O rff E D 2877 p. 29.

A terceira se assemelha à primeira, é indubitavelmente silábica, quando tenor e 0 baixo cantam a primeira frase, repetida no contralto com soprano, fazendo a mesma duplicação, tendo baixo e tenor paralelamente em terça:

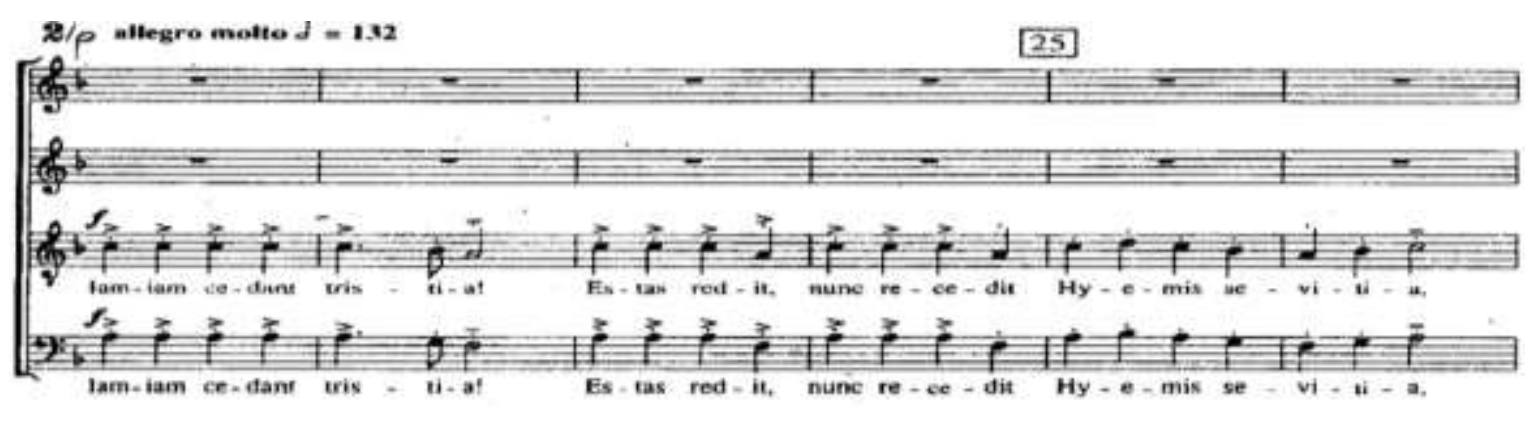

D escrição: Frase 3 - 0 minia sol temperat.

Fonte: C armina Burana, C arl O rff ED 2877 p. 29.

Ritmicamente, temos 0 seguinte esquema: temos $4 / 1$ no primeiro compasso do movimento, 4/2 (nos compassos de 2 a 13) e passa a 2/2 (nos compassos 14 a 39), repetidas 3 vezes.

Tanz é um movimento só para orquestra, sem coro, em D ó M aior, inconstante quando à formulas de compassos. Inconstante quanto à fórmulas de compassos. T emos 2/4 
(no primeiro e segundo compasso do movimento), o terceiro compasso é $3 / 8$ e o quarto é 2/8; nos próximos compassos, ficam alternando $4 / 4$ e 3/8, aparecendo de vez enquanto entre essa alternância 2/8 (nos compasso 20 e 70), e também 2/4 (nos compassos 22 e 72), 6/8 (nos compassos 37, 47 e 50) e 12/8 (nos compassos 41 e 51).

F loret silva está na tonalidade de Sol M aior, um movimento neumático que possui alguns melismas, sendo antifônico, formado por dois coros cantando alternadamente, um coro grande e um coro piccolo. Começa com o coro a seis vozes (baixo, tenor 1 , tenor 2 , contralto, soprano 1 e soprano 2), em que o baixo e contralto cantam a mesma linha melódica em oitavas diferentes, o mesmo acontece entre tenor 2 e soprano 2, tenor 1 e soprano 1; na primeira parte, 0 rff pode ter tido a influência do fauxbordon, na primeira frase as vozes caminham juntas em maioria em intervalos de terças e formando acordes.

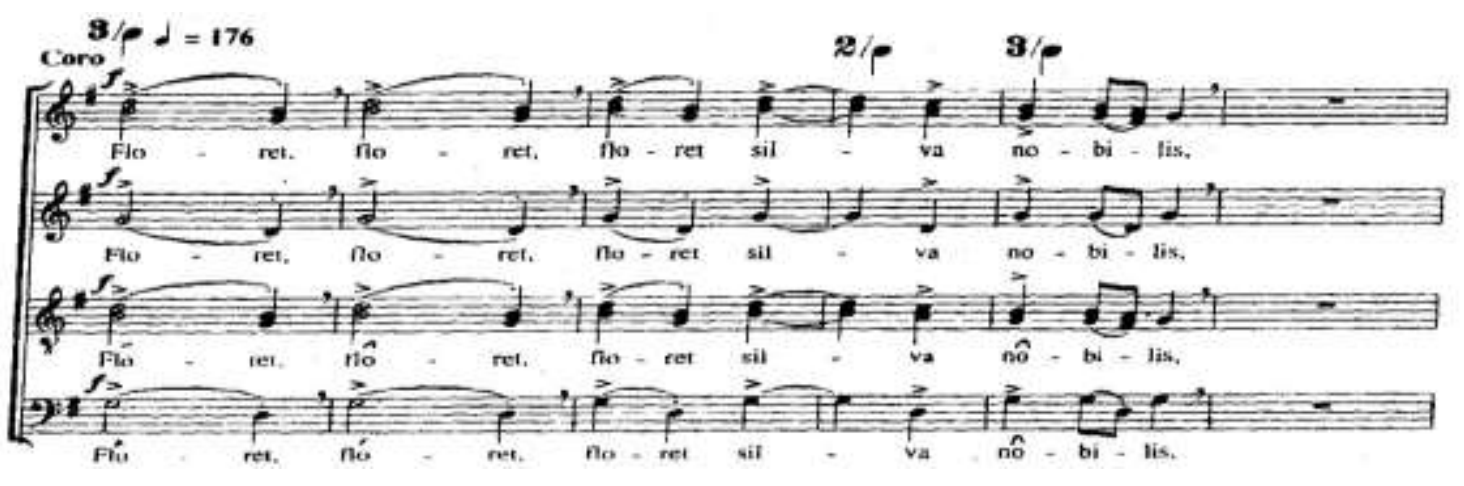

D escrição: F rase 1 - Floret silva.

Fonte: C armina Burana, C arl O rff ED 2877 p. 43.

A segunda frase, a quatro vozes, onde o baixo mantém a nota sol e o tenor uma quinta acima o ré, se superpõe o contralto e o soprano fazendo breves melismas mantendo num intervalo de terça, até os dois últimos compassos da frase, onde o baixo mantém o ré junto com o tenor, e contralto simultaneamente ao soprano fazem melismas de quatro notas, porém mantêm os intervalos entre elas de terças:

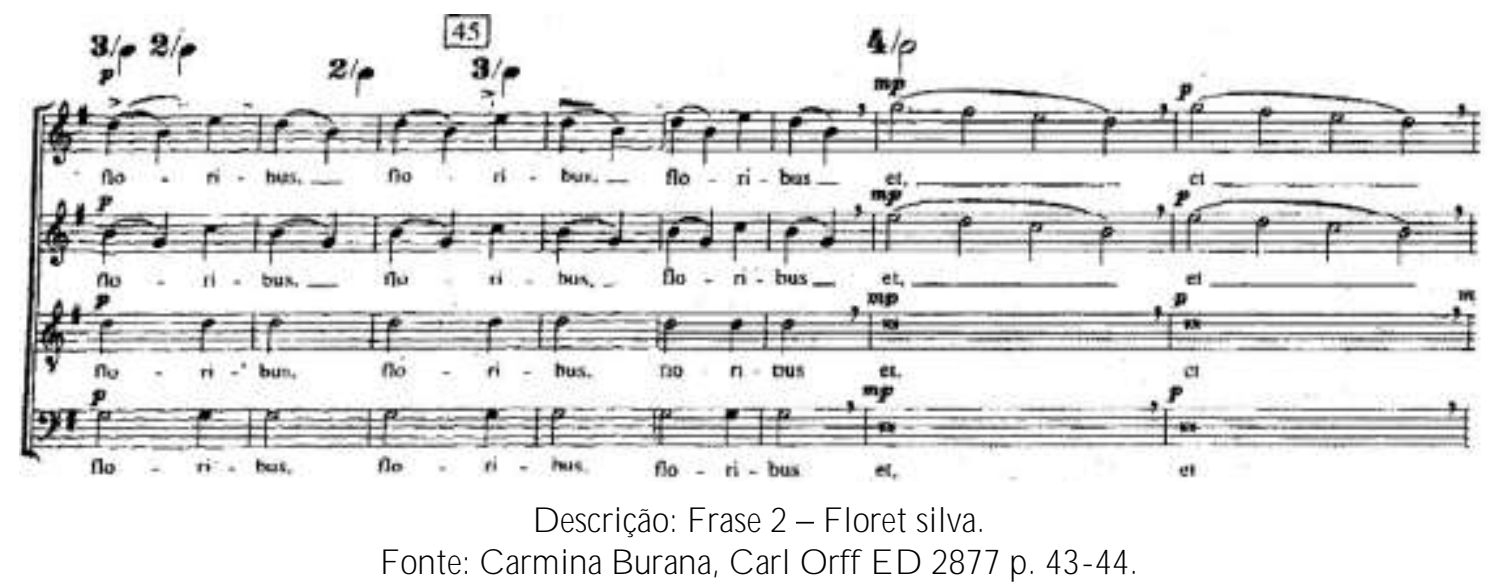


Chegando a parte do coro piccolo em duas frases, onde a segunda é repetição da primeira, feita por contralto e soprano que seguem superpostos em terça paralela algumas notas em uníssono, e depois elas sustentam a nota sol por quatro compassos em oitavas: 


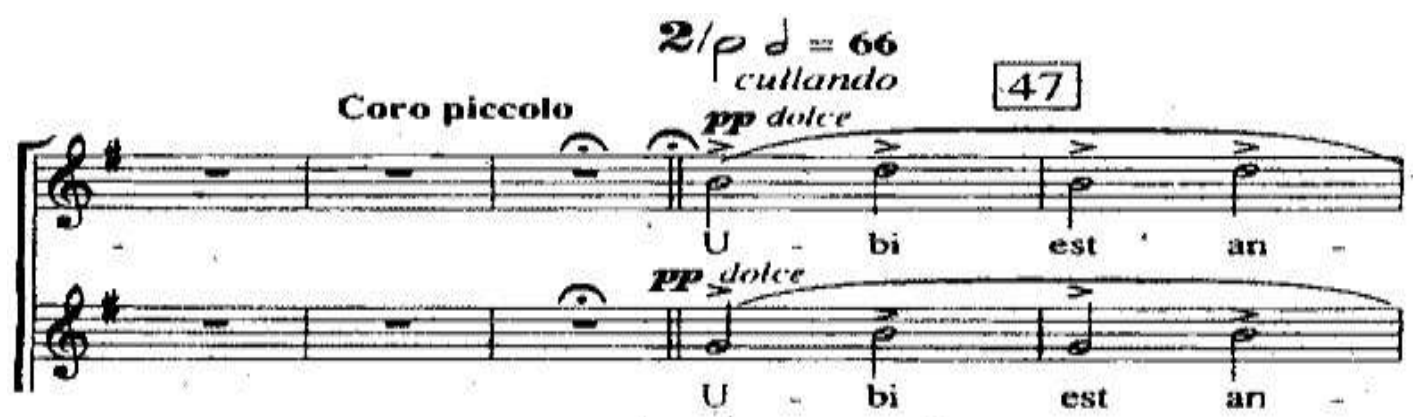

D escrição: 2 compassos da frase 1 coro piccolo - Floret silva.

Fonte: C armina Burana, C arl O rff ED 2877 p. 46.

Q uando entra na parte do tenor (no compasso 50), se percebe a influência de hoqueto:

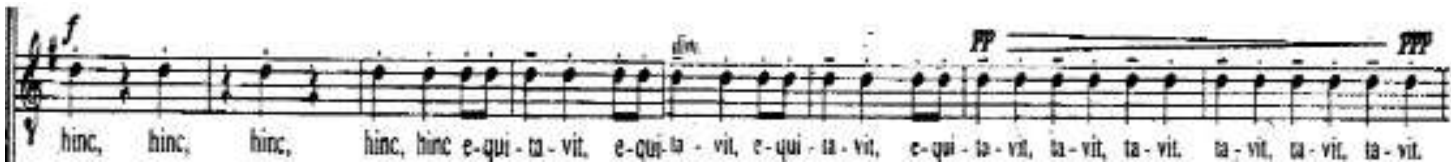

D escrição: Frase 2 coro piccolo - Floret silva.

Fonte: Carmina Burana, Carl O rff ED 2877 p. 46.

Logo em seguida, uma frase a três vozes (contralto, soprano 1 e soprano 2) caminham em paralelas em terças formando acordes:

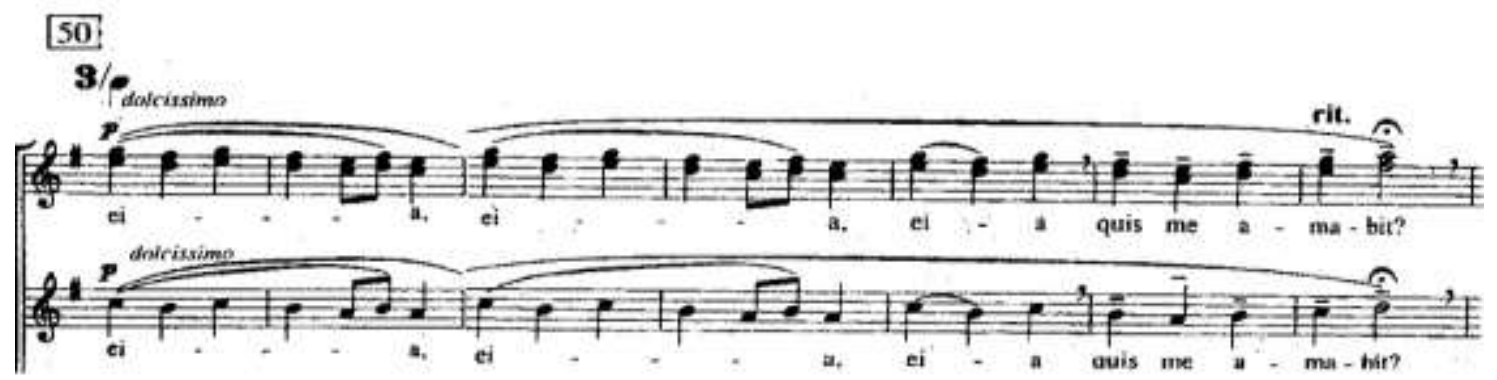

D escrição: Frase 3 coro piccolo- Floret silva.

F onte: C arminaBurana, C arl O rff ED 2877 p. 46-47.

D epois o ritmo harmônico para e essas vozes mantêm sete compassos com o acorde de sol na segunda inversão, quando a voz mais grave que nesse caso é a contralto mantém o ré, a soprano 2 mantém o sol, e a soprano 1 em si:

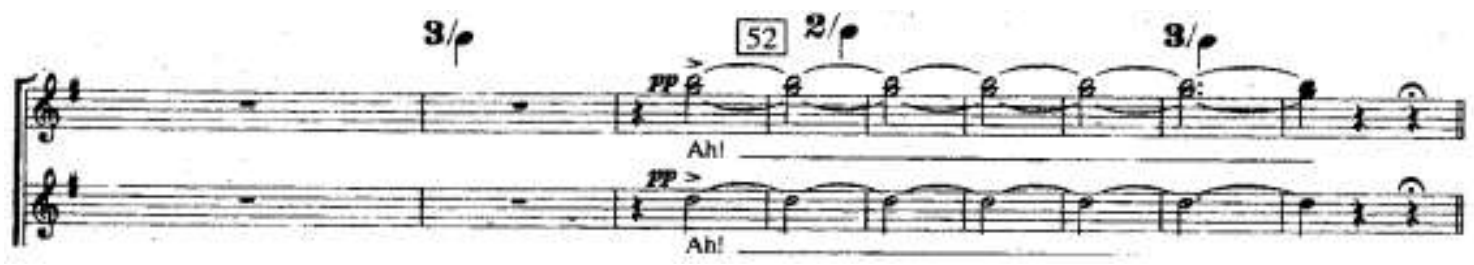


Dos compassos 85 a 167 do movimento, se repete a mesma estrutura com alterações no texto. Já a parte rítmica O rff se serve de variadas fórmulas de compassos: primeira frase (compasso 1 ao 5), começa em 3/4 e no penúltimo compasso vai para 2/4 e depois volta para 3/4. A ntes do coro piccolo (compasso 28), O rff utiliza alternância de compassos 2/4 e 3/4 (do compasso 7 ao 14) e em dois compassos o 4/2 (no compasso 15 e 16), e depois volta alternar entre $3 / 4$ e $2 / 4$ (do compasso 17 ao 23) e os últimos cinco compassos são em 3/4. No coro piccolo, três compassos são em 2/2 (compasso 28, 29 e 30) e nos compassos seguintes vem uma alternância entre $3 / 4$ que dura um compasso e 2/4 que dura quatro compassos, repete essa estrutura e finaliza em $3 / 4$, repete tudo até o final do movimento.

Chramer, gip die varwe mir está na tonalidade de Sol M aior, sendo neumático, predominantemente melismático, em responsório com coro piccolo de soprano em 4/4, um solo com extensão de sexta (sol-mi):

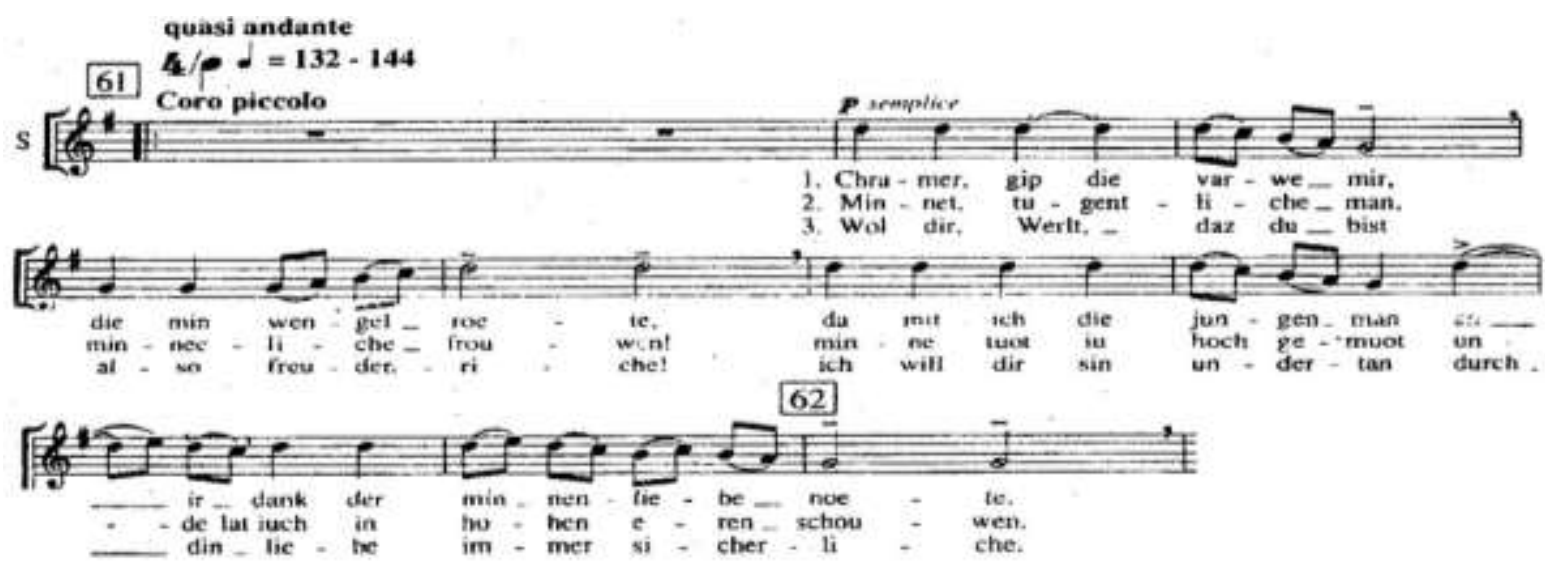

D escrição: Frase coro piccolo soprano - C hrmer, gip die varwe mir.

Fonte: C armina Burana, C arl O rff ED 2877 p. 54.

$\mathrm{Na}$ estrada do Coro grande (baixo, barítono 1, barítono 2, tenor, contralto e mezzo), no compasso 12 do movimento vai para 2/2, e o baixo mantém a nota lá em valores longos, e as outras vozes caminham fazendo acordes, em que os barítonos e o tenor têm dependência rítmica, como contralto e mezzo:

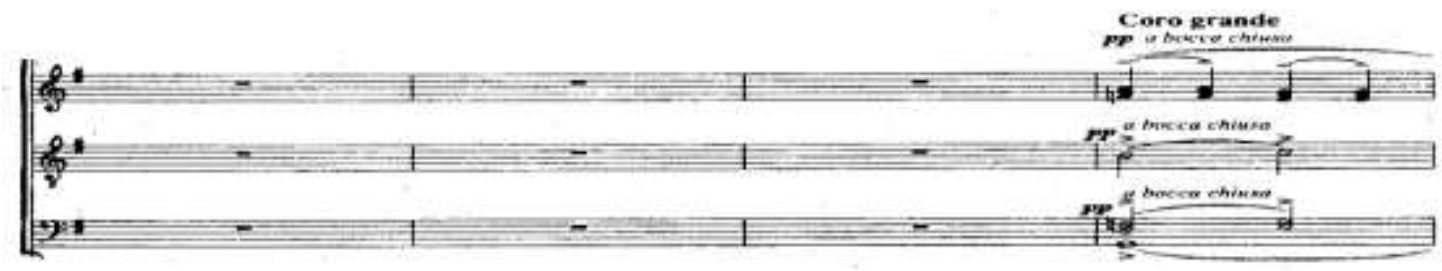


D escrição: Começo do coro grande - C hrmer, gip die varwe mir.

Fonte: C armina Burana, C arl O rff ED 2877 p. 55.

D epois vai para um coro piccolo de soprano 1, soprano 2 e coro grande de tenor juntos no compasso 20, quando o tenor mantém a nota si, enquanto as sopranos caminham paralelamente em terça e caminhando melodicamente com predominância também em intervalos de terça (fauxbordon), é composta em 4/4; no compasso 23, vai para 3/4 e volta para 4/4 no compasso 24; e nos dois últimos compassos do movimento, tem um coro grande em $2 / 2$, mantendo a mesma estrutura do coro grande anterior.

Reie tem a tonalidade de D ó $M$ aior e começa num movimento orquestral dividido em duas partes; a primeira tem uma frase de sete compassos, em que cada um muda a fórmula na seguinte sequência: começa com $2 / 2$, depois 3/2, 5/2, 2/2. 3/2, 7/2 e finaliza em 2/2, e repete o mesmo formato; na segunda parte (compasso 15 ao 25), tem duas frases que têm dois compassos em 4/2 e um em 8/2, repete e para finalizar, 4 compassos em 4/2 e o último compasso em 2/2. Em Swaz hie gat umbe, há modulação para D ó M aior. É neumática, silábica, directa apesar do início parecer aintifônico, quando a textura apresenta o baixo e o tenor em paralela e em terça, cantando uma frase e contralto e soprano repetindo essa frase uma oitava acima:

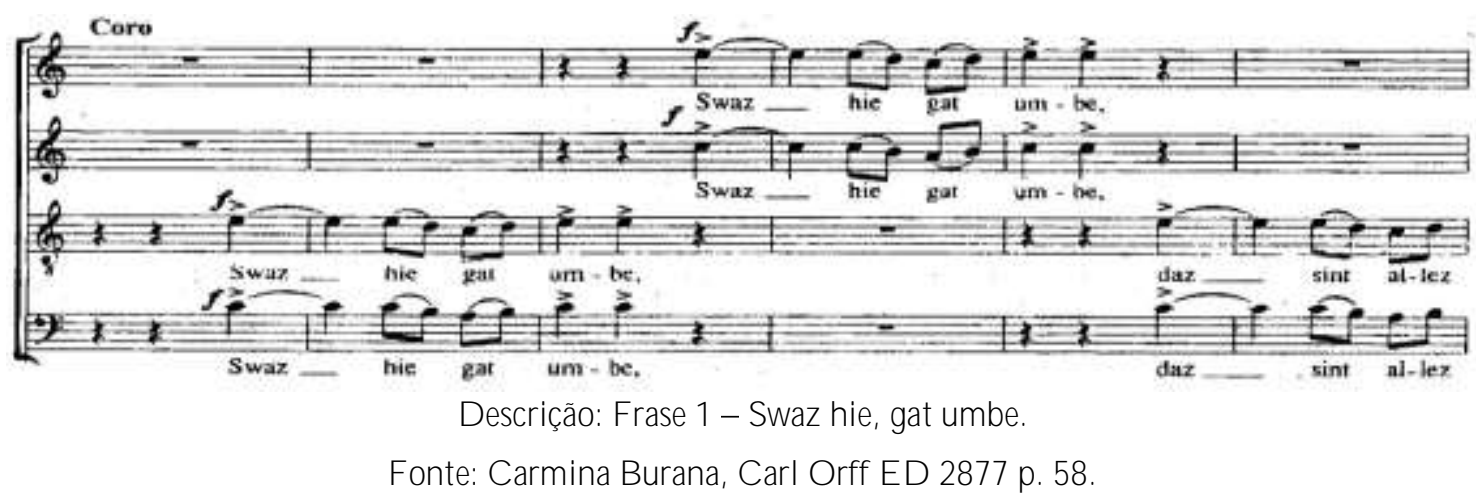

N os cinco compassos finais da primeira parte, entra todas as vozes cantando juntas, baixo e contralto, tenor e soprano paralelamente em oitavas, depois (em c. --) modulando para o homônimo maior, agora em uma construção a seis vozes, produzindo o acorde de Lá M aior. Assim distribuído, baixo e contralto mantêm a fundamental lá; barítono e mezzo a terça, a nota dó; e tenor e soprano a quinta, nota mi que também é dividida em duas partes. A estrutura rítmica apresenta as seguintes fórmulas de compassos: começa em $3 / 4$ e somente muda um compasso em 1/4 (compasso 19) para mudar para a parte em que 
as quatro vozes cantam em uníssono, que também começa em 3/4 que tem uma frase com cinco compassos em que os dois últimos são em 2/4, e muda novamente para 3/4 no compasso 25 e vai até o final do movimento: 


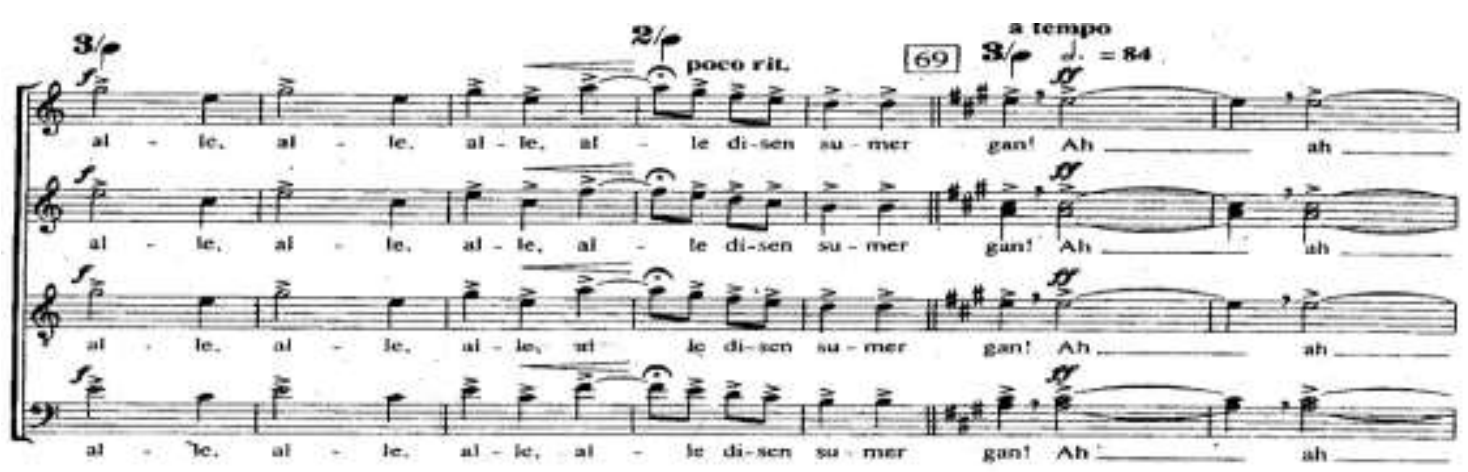

D escrição: Final da 1a parte (lá menor) e começo 2ª parte (L á M aior) - Swarz hie, gat umbe.

Fonte: Carmina Burana, C arl O rff E D 2877 p. 59.

Chume, dhum, geselle min continua no ritmo $3 / 4$, deixado pela música anterior e vai até o final, assim, volta para a tonalidade de Dó M aior e é cantado por coro piccolo, neumática com predominância melismática, quando quase todas as sílabas são melismas, é responsório pois começa com um solo para contralto, com extensão de quinta (dó-sol):

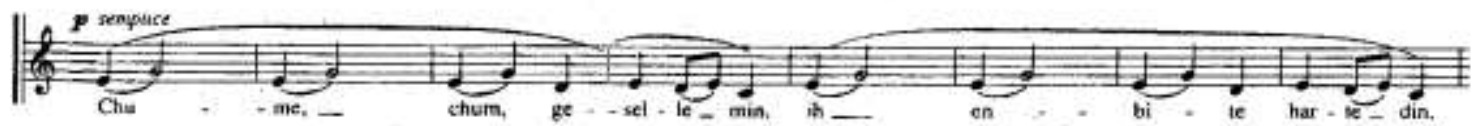

D escrição: Frase solo contral to - C hume, chum, geselle min.

Fonte: C armina Burana, C arl O rff ED 2877 p. 60.

E depois tem uma resposta do baixo, mantendo uma única nota, a nota dó, barítono alternando em sol e lá, e tenor 1 e tenor 2, caminhando livre, porém, dependentes um do outro, a única parte que desprende os dois é um breve melisma:

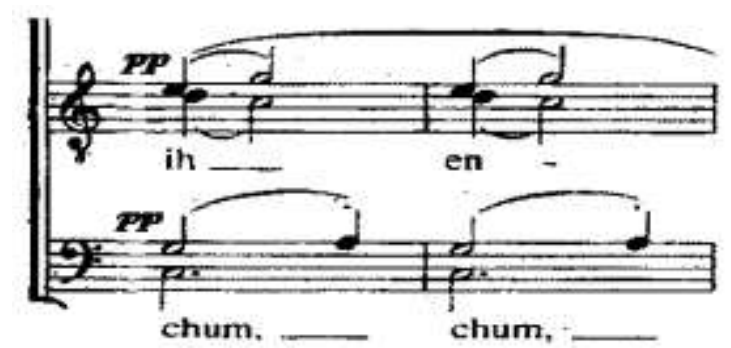

D escrição: D ois primeiros compassos da resposta - C hume, chum, geselle min.

Fonte: C armina Burana, C arl O rff E D 2877 p. 61.

Terminando esse movimento, repete Swaz hie gat umbe. Were diu werlt alle min tem a tonalidade de Dó M aior, a fórmula de compasso 4/4 e o movimento inteiro, classificado como directo e neumático, com melismas até de onze notas. 0 movimento 
inteiro a quatro vozes (baixo, tenor, contralto e soprano) cantando em uníssono e em oitava: 


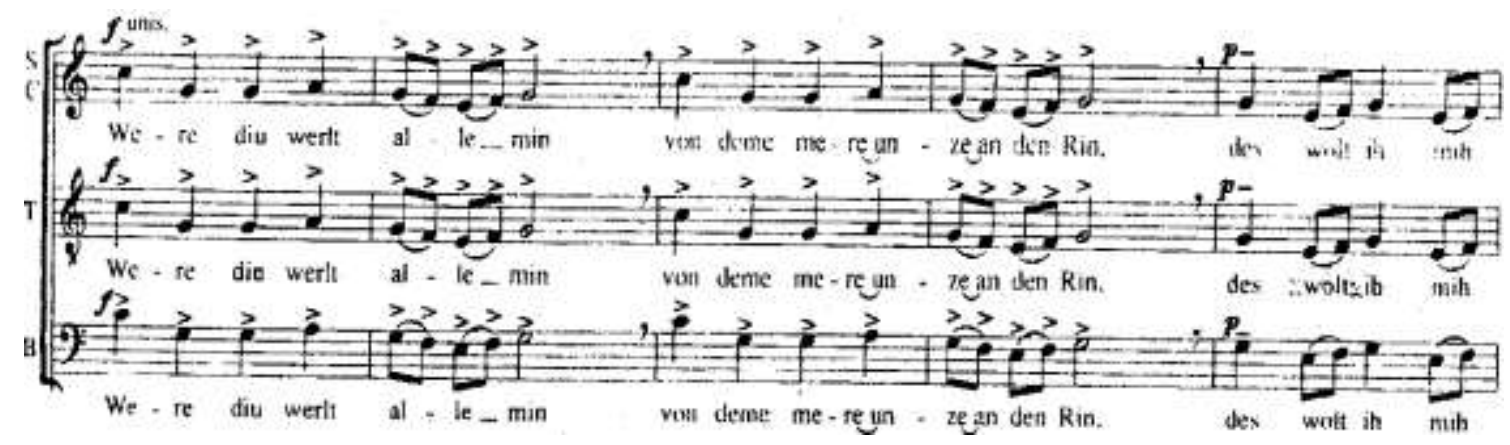

D escrição: F rase 1 - W ere diu werlt alle min.

Fonte: C armina Burana, C arl O rff ED 2877 p. 65.

A segunda parte de C armina Burana: In T aberna, uma parte cantada somente com voz masculina, começa com o movimento E stuans interius em lá menor, para barítono solo, directo e neumática com predominância silábica, a fórmula de compasso 4/4 e só finaliza 0 último compasso em 1/4:

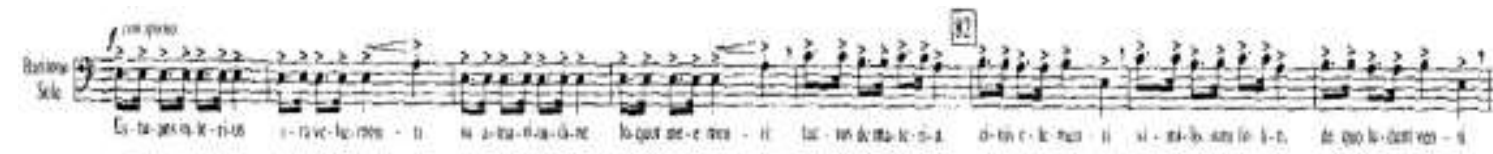

D escrição: F rase 1 - E stuans interius.

Fonte: C armina Burana, C arl O rff E D 2877 p. 67.

Olim lacus colueram está na tonalidade de Fá\# menor, um movimento para tenor solo, neumática com predominância silábica, antifônica, um coro masculino (baixo, barítono, tenor 1 e tenor 2 ) responde o solista, a parte rítmica é 4/4 e quando entra o coro vai para $4 / 2$, e a música repete mais duas vezes com texto diferente para 0 solista, mas 0 coro mantém a mesma frase:

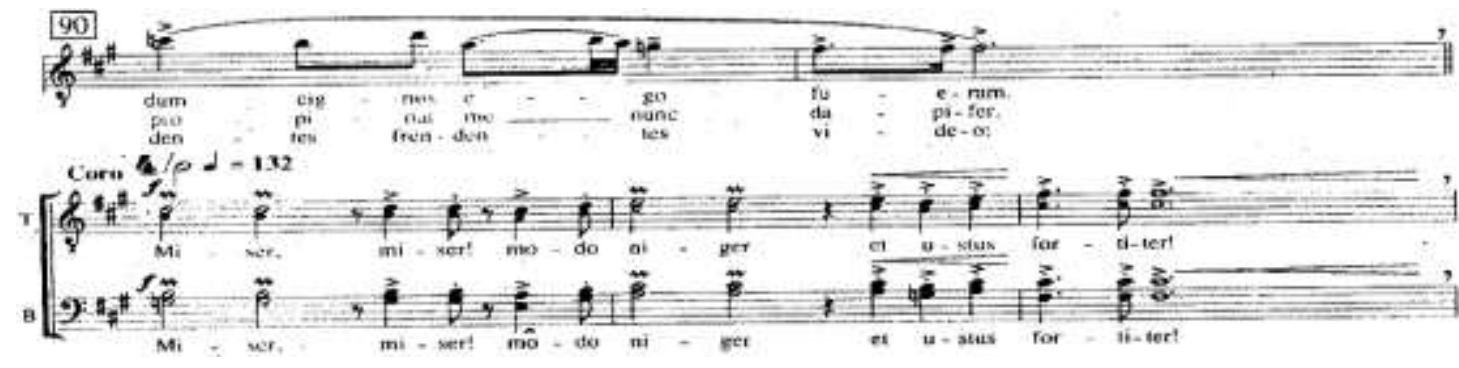

D escrição: F rase solista e coro - O lim lacus colueram.

Fonte: C armina Burana, C arl O rff E D 2877 p. 72.

E go sum abbas, em ré dórico, começa numa frase para barítono solo, com liberdade total do solista na questão do tempo de cada nota: 


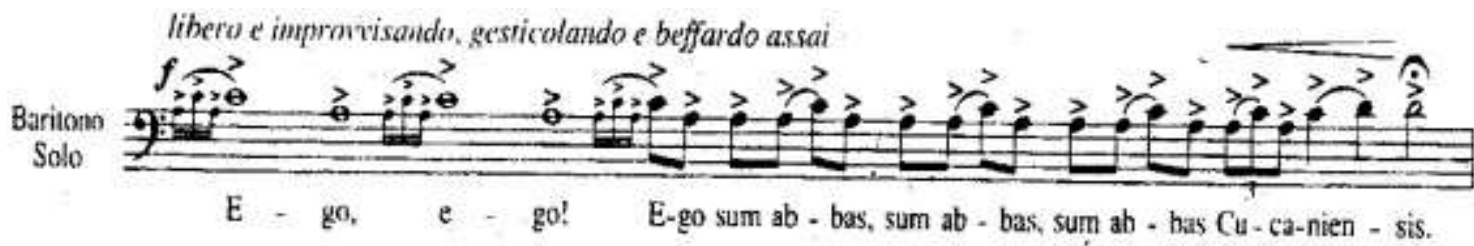

D escrição: Frase Barítono Solo - E go sum abbas.

Fonte: C armina Burana, C arl O rff ED 2877 p. 73.

Q uando entra a orquestra tem dois compassos em 4/4 (compasso 2 e 3 do movimento), depois volta para o solo do barítono totalmente livre, depois que volta a orquestra em 4/4 (compasso 5) vai até o final do movimento com essa fórmula de compasso, um movimento neumático e antifônico, um coro masculino (baixo, barítono, tenor 1 e tenor 2) responde o solista fazendo o acorde de ré menor:

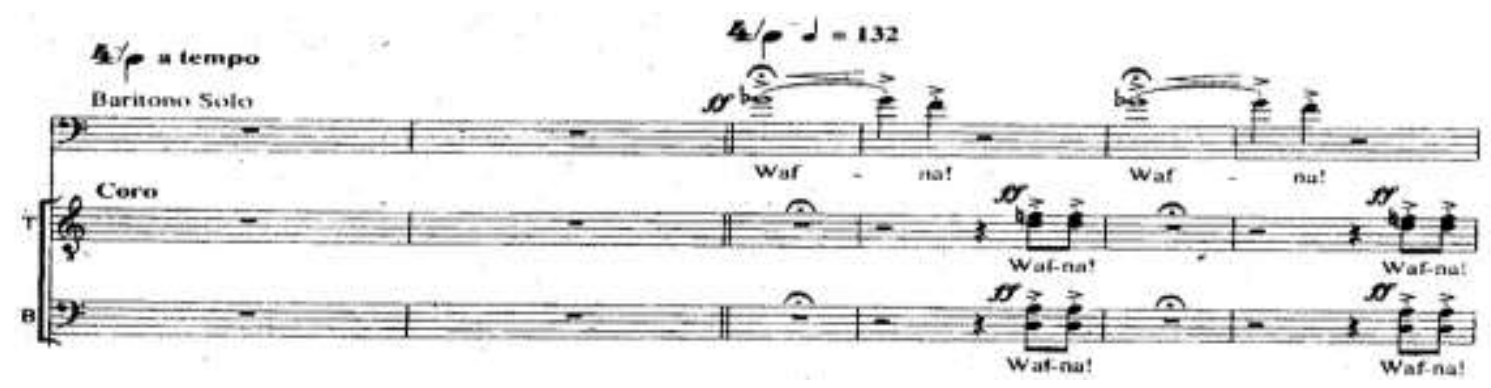

D escrição: Solo e resposta - E go sum abbas.

Fonte: Carmina Burana, C arl O rff ED 2877 p. 73.

In taberna quando sumus está na tonalidade de lá menor, é neumático e directo, em que a maioria do movimento possui apenas uma linha melódica, sendo uníssonos; o baixo e o tenor cantam em uníssono:

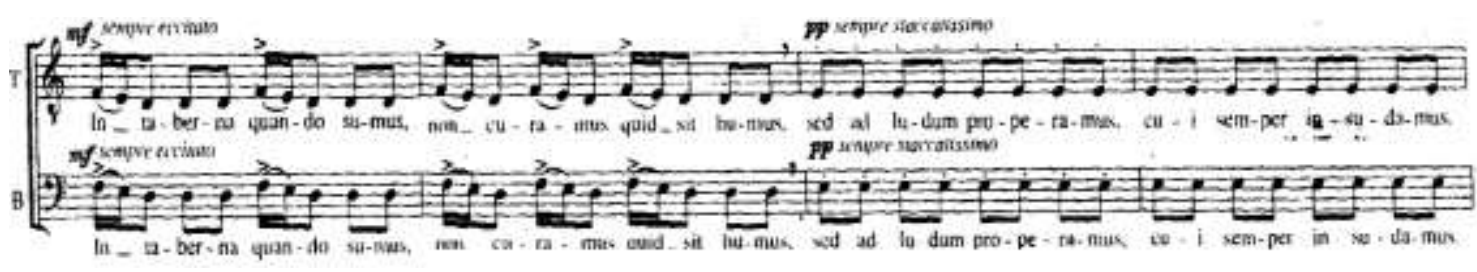

D escrição: Frase 1 - In taberna quando sumus.

Fonte: Carmina Burana, C arl O rff ED 2877 p. 75. 
A parte rítmica começa também em 4/4; numa segunda parte, no compasso 25 , vai para 3/2 e o próximo em 4/4, repete novamente $03 / 2$ e 4/4 nos compassos 27 e 28 respectivamente, e continua até fazer essa variação novamente nos compassos 34 ao 37; no próximo compasso, continua em 4/4 e a música vai para a tonalidade de lá maior, porém, continua o baixo e o tenor em uníssono, até numa parte (compasso 67) em que entra 0 barítono fazendo a terça do baixo e 0 tenor passa a fazer a sexta do baixo, característica do fauxbordon:

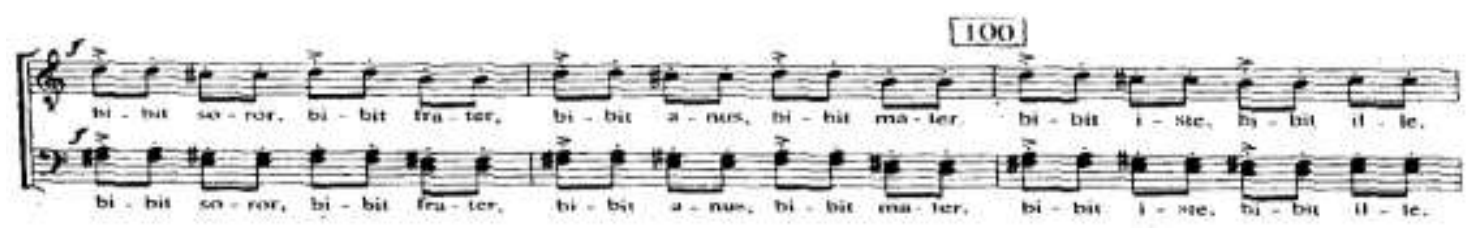

D escrição: Baixo, barítono e tenor - In tarberna quando sumus.

Fonte: C armina Burana, C arl O rff ED 2877 p. 81.

A terceira parte: Cour d'Amours, com Amor volat undique um movimento neumático em responsório, que começa na tonalidade de Ré $M$ aior em $2 / 2$, a introdução de quatro compassos; depois vai para $3 / 4$ e no compasso 13 , que entra o coro ragazzi uma frase que tem característica de lá frigio, em 4/4:

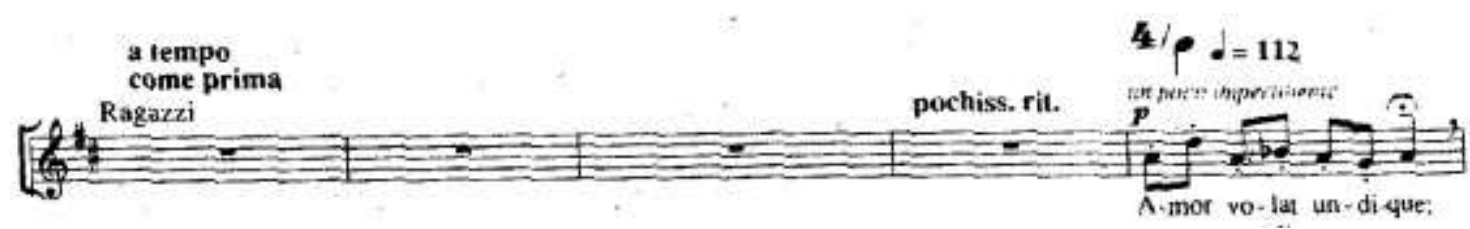

D escrição: Frase ragazzi - A mor volat undique.

Fonte: Carmina Burana, C arl O rff ED 2877 p. 84.

N o compasso seguinte, volta para $3 / 4$, somente orquestra, e repete até entrar o solo da soprano (compasso 29), que vai para tonalidade relativa, si menor, em 4/4:

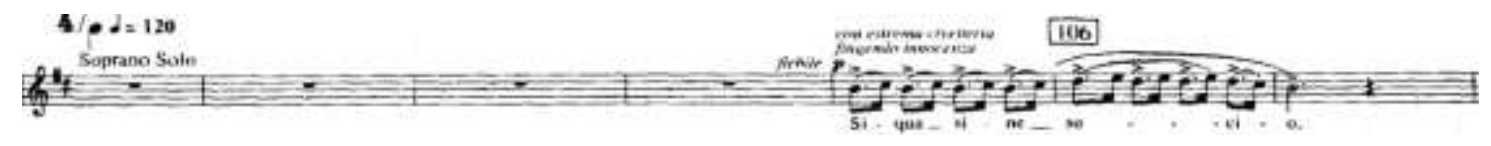

D escrição: Frase soprano - A mor volat undique.

Fonte: C armina Burana, C arl O rff E D 2877 p. 85. 
$\mathrm{Na}$ quarta e última frase da soprano (compassos 47 ao 58): começa o primeiro compasso em 2/4 e depois volta para 4/4 para três compassos seguintes e depois vai para $3 / 4$ até 0 final da frase, quando volta o coro ragazzi (no compasso 59) na mesma estrutura anterior.

Dies, nox et omnia é um movimento para barítono solo, neumático e directo, na tonalidade de fá\# menor, porém possui uma curiosidade, sua maior parte nos dá a sensação de mi hipomixolídio, como nas primeiras frases cantada pelo barítono:

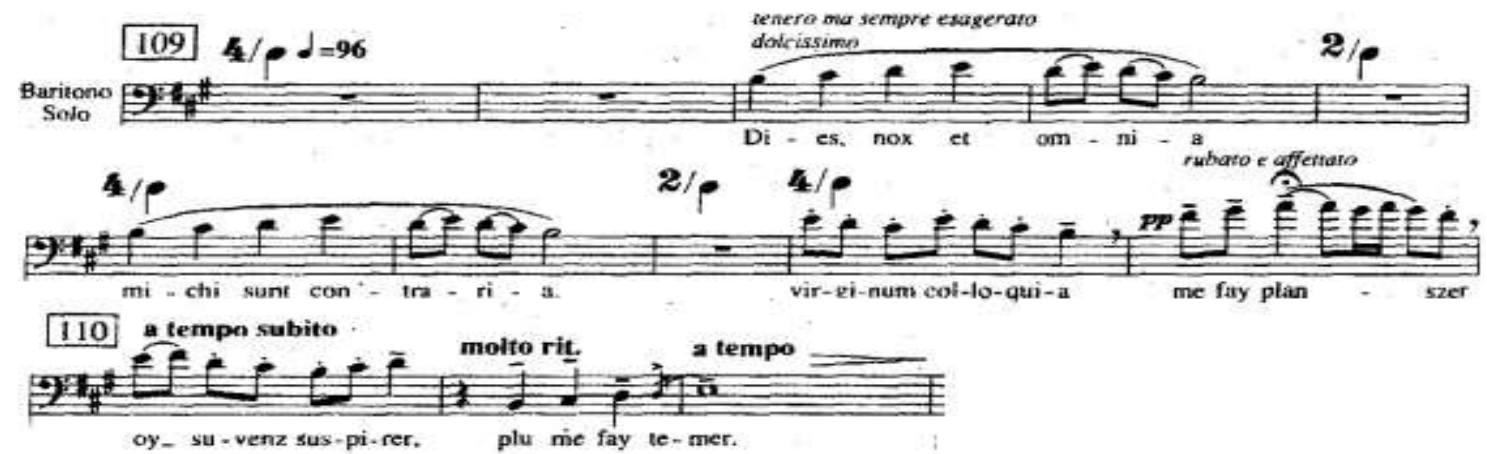

D escrição: Primeiras frases - D ies, nox et omnia.

Fonte: Carmina Burana, C arl O rff ED 2877 p. 87.

No compasso 22, ele faz um melisma de vinte e duas notas em fá\# menor, ele repete a mesma ideia com melisma no compasso 35 (com algumas notas mais agudas) e finaliza o movimento. A parte rítmica fica variando entre $4 / 4$ e 2/4 e também utiliza 0 rubato.

Stetit puella é um movimento para soprano solo que possui praticamente a mesma estrutura da música anterior, um movimento neumático e directo, com fórmula de compasso 2/4, e que utiliza o modo de mi mixolídio, pois, utiliza a escala de mi maior, porém com a sétima menor.

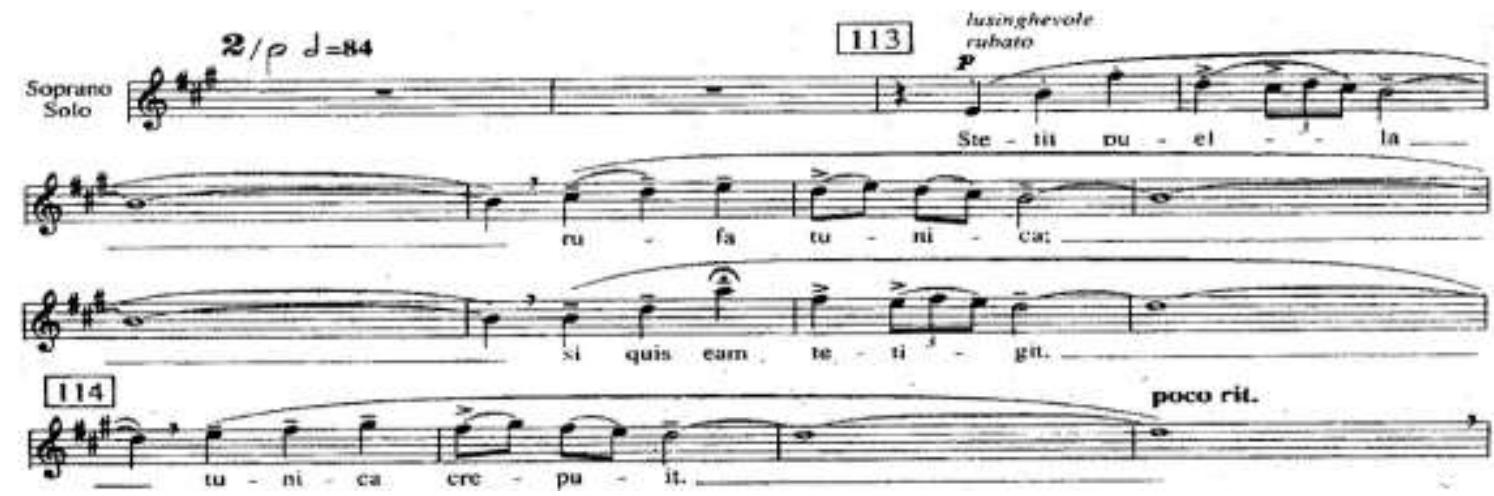

D escrição: F rase soprano - Stetit puella. 
Essa frase é desenvolvida, entretanto continua no modo de mi mixolídio.

Circa mea pectora tem a tonalidade de mi menor (modo eólio). É um movimento para barítono solo, neumático, responsório e antifônal, porque começa com o solista e depois um coro masculino (baixo, barítono e tenor) responde o solista, e depois um coro feminino (contralto e soprano) canta alternadamente com o coro masculino:

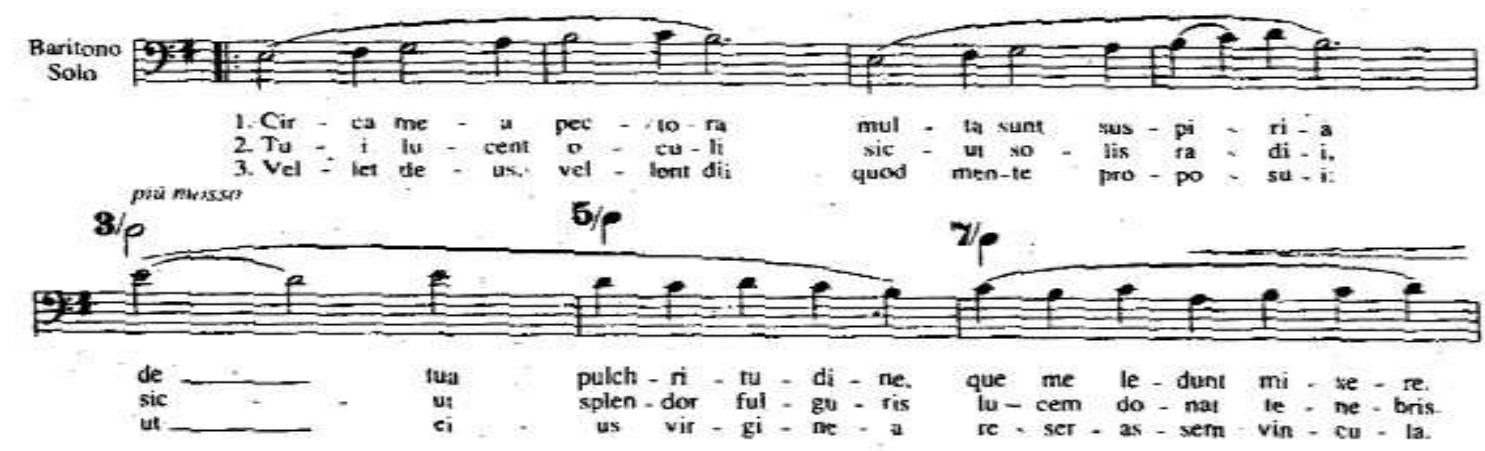

D escrição: F rase 1 barítono - Circa mea pectora.

Fonte: C armina Burana, C arl O rff E D 2877 p. 92.

No início, tem duas frases de dois compassos para solo de barítono em âmbito de quinta (mi-si) com fórmula de compasso 6/4, depois prossegue com o compasso 5 em 3/2, no compasso 6 em 5/4 e compasso 7 em 7/4 e depois entra o coro masculino, também com duas frases, ambas com dois compassos cada, em 5/4 (corresponde a duas mínimas pontuadas), com movimentos livres, contudo dependentes ritmicamente:

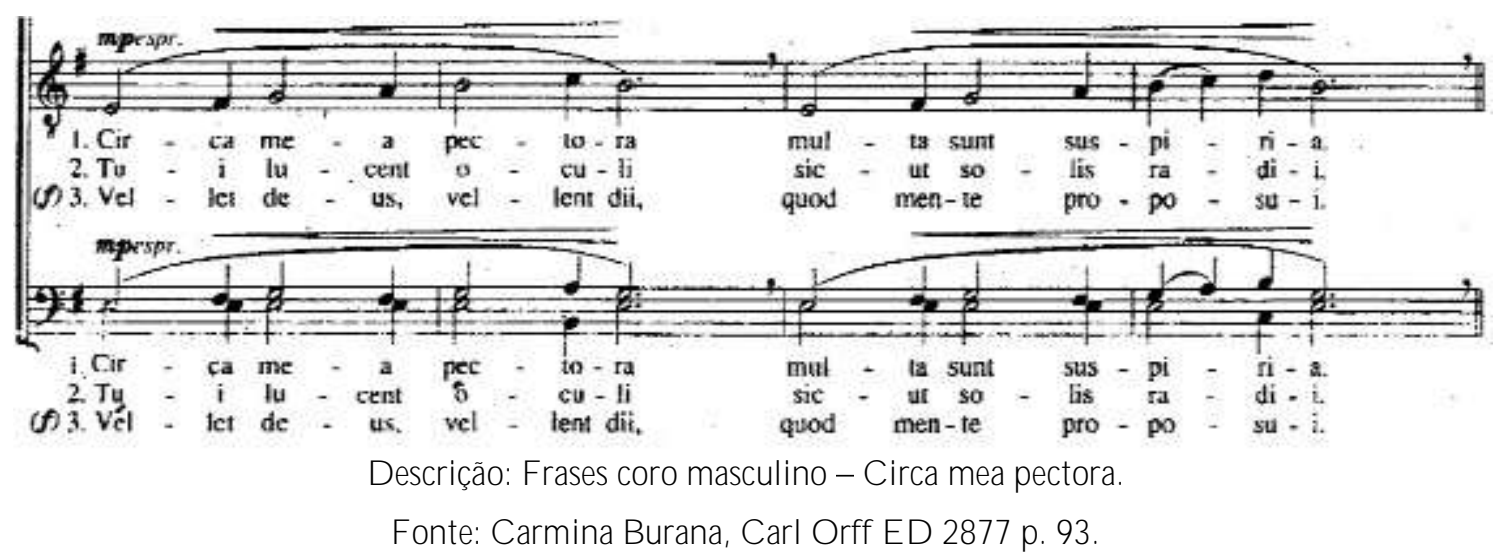

Q uando entra o coro feminino no compasso 12 , prossegue o restante da música em 2/2, se modula para M i M aior (modo jônico), em que contralto e soprano cantam em 
uníssono, e o coro masculino canta a mesma frase logo em seguida; depois o coro feminino canta novamente com a diferença no final, quando o soprano, às vezes, está em uníssono e, às vezes, em oitava com contralto:

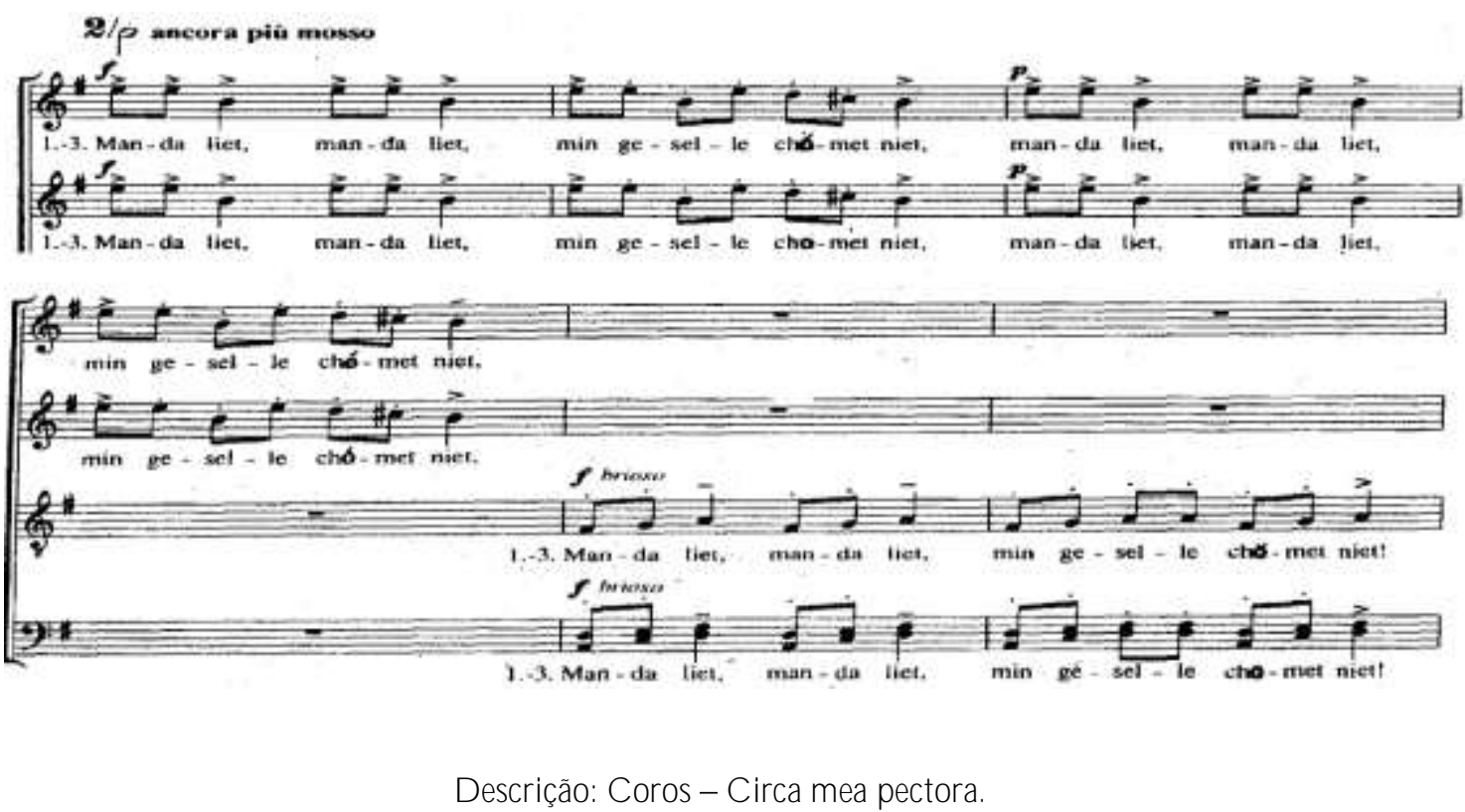

Fonte: C armina Burana, C arl O rff E D 2877 p. 93-94.

Si puer aum puellula é um movimento totalmente a capela, o único em toda obra. Utiliza o modo si dórico, neumático, responsório e antifônico; dois coros cantam alternadamente, um coro de vozes graves masculina (baixo 1, baixo 2 e barítono) e um coro de vozes agudas masculinas (tenor 1, tenor 2 e tenor 3 ), e o coro de vozes graves responde o solista; neste casso, o barítono, e utiliza a fórmula de compasso 2/4. 0 movimento começa com o coro de vozes graves, e logo em seguida o coro de vozes agudas, as três vozes dos coros sempre caminham em terças formando acordes: 

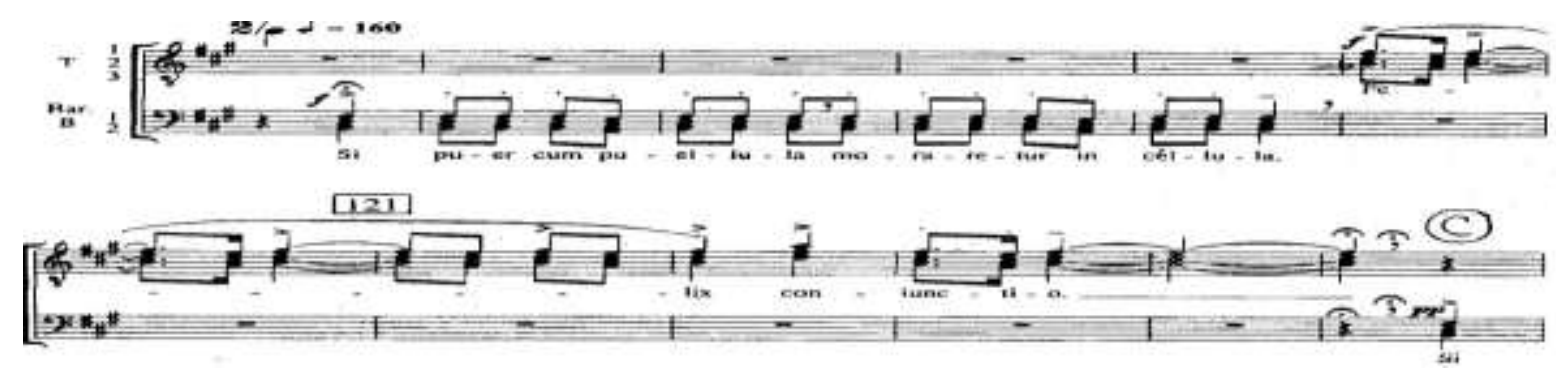

D escrição: F rases coros - Si puer cum puellula.

Fonte: C armina Burana, C arl O rff E D 2877 p. 95

A mbas as frases são repetidas, e o coro de vozes graves faz uma frase e logo em seguida o solista canta outra, e eles ficam alternando até entrar novamente as frases iniciais dos coros:

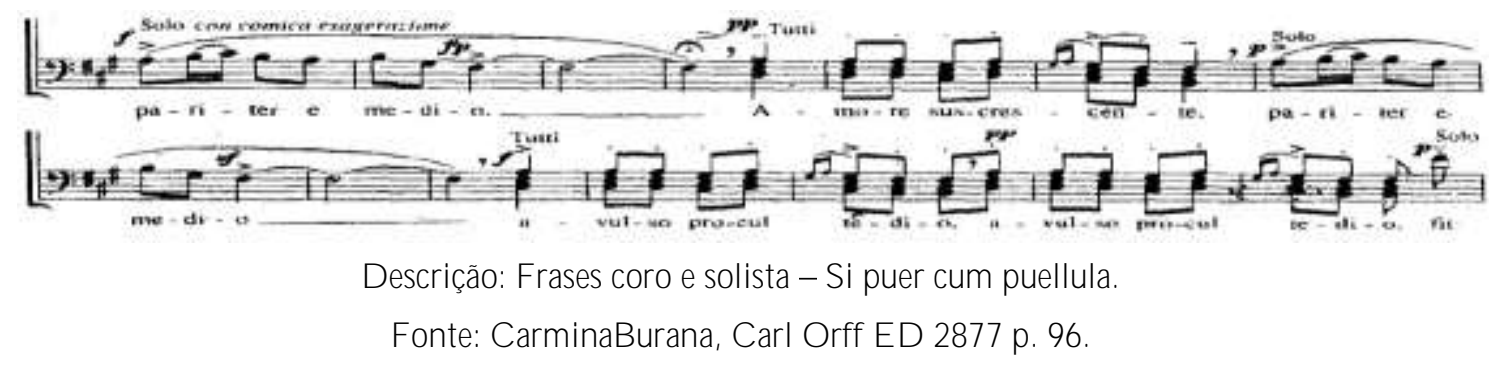

Veni, veni, venias também é um movimento antifonal e responsório, movimento com dois coros, com tonalidade de Sol M aior; no começo do movimento, o coro II se inicia com três vozes femininas (contralto, soprano 1 e soprano 2), fazem uma frase com 0 intervalo fixo de terça entre elas e um coro masculino (baixo, tenor 1 e tenor 2 ) respondem com outra frase também caminhando em terças:

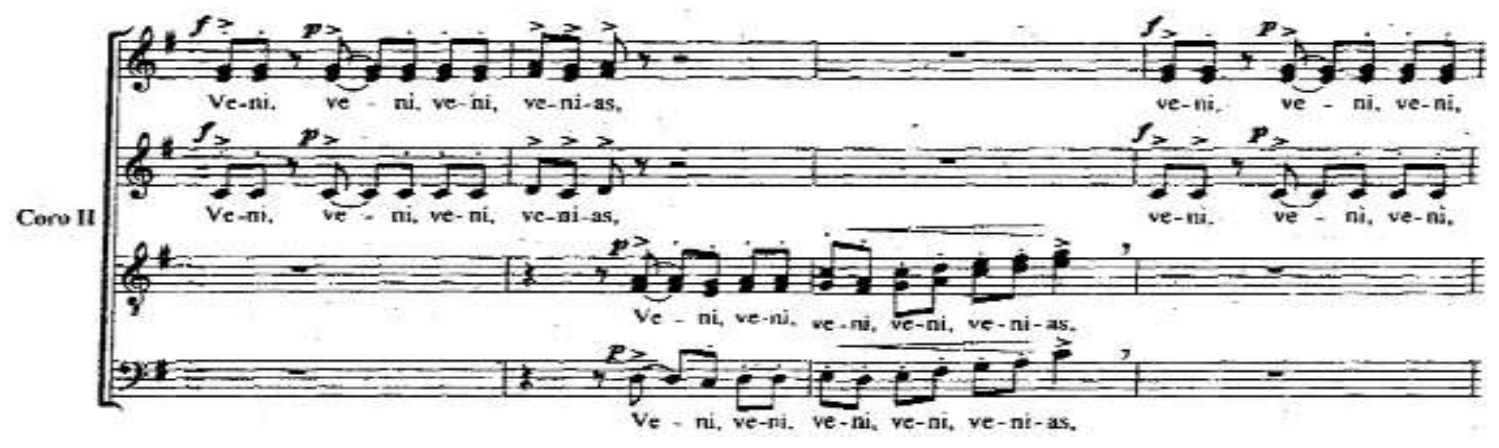

D escrição: F rases vozes femininas e masculinas - V eni, veni, venias. 
Fonte: C armina Burana, C arl O rff E D 2877 p. 97.

Se mantém assim até entrar todas as seis vozes juntas, quando contralto duplica 0 baixo em oitava e o mesmo para tenor 1 e soprano 1, tenor 2 e soprano 2, quando entra os dois coros juntos, vai para a tonalidade de ré menor, o coro I tem 4 vozes (baixo, tenor, contralto e soprano) fazem uma única linha melódica em uníssono e oitavas, enquanto 0 coro II responde com o mesmo esquema do início da música: 


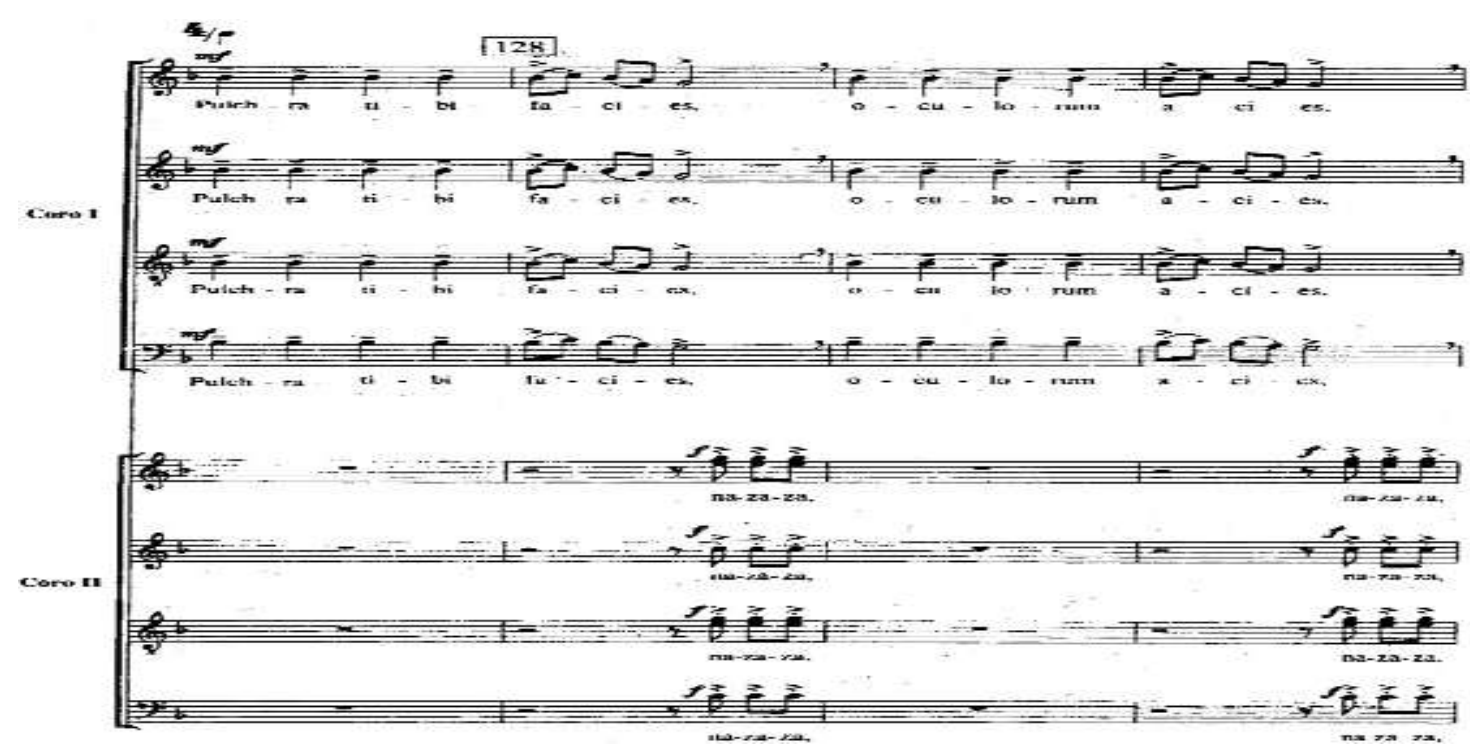

D escrição: C oro I e C oro II - Veni, veni, venias.

Fonte: C armina Burana, C arl O rff ED 2877 p. 99.

O s últimos compassos do movimento estão em Ré M aior. A parte rítmica começa o coro II em 4/4, nos seis compassos antes de entrar o coro I junto com o coro II, tem dois compassos em 3/4, um em 4/4, e três em 2/4, quando entra o coro I vai para $4 / 4$ e vai até 0 final.

In trutina continua em Ré M aior, um movimento para soprano solo, neumático e directo, varia entre 4/2 e 3/2, e 4/2 2/2:

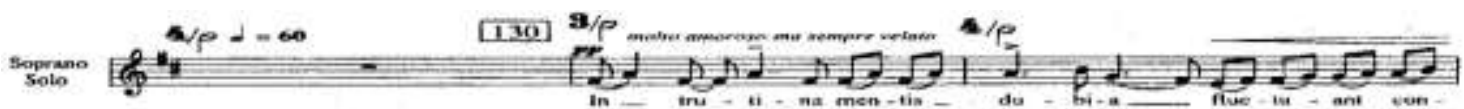

D escrição: Primeiros compassos da frase (soprano solo) - In trutina.

Fonte: C armina Burana, C arl O rff E D 2877 p. 103.

Tempus est iocundum, movimento para coro, soprano solo e barítono solo, e coro ragazzi, em Ré M aior, porém ele utiliza muito a quarta aumentada, passando a sensação do modo lídio. A estrutura dessa música é a seguinte: começa o coro com oito vozes (baixo, barítono, tenor 1, tenor 2, contralto, mezzo, soprano 1 e soprano 2), com movimentos livres, porém dependente no ritmo, onde as vozes graves femininas duplicam as vozes graves masculinas, e o mesmo acontece com as vozes medias e agudas: 


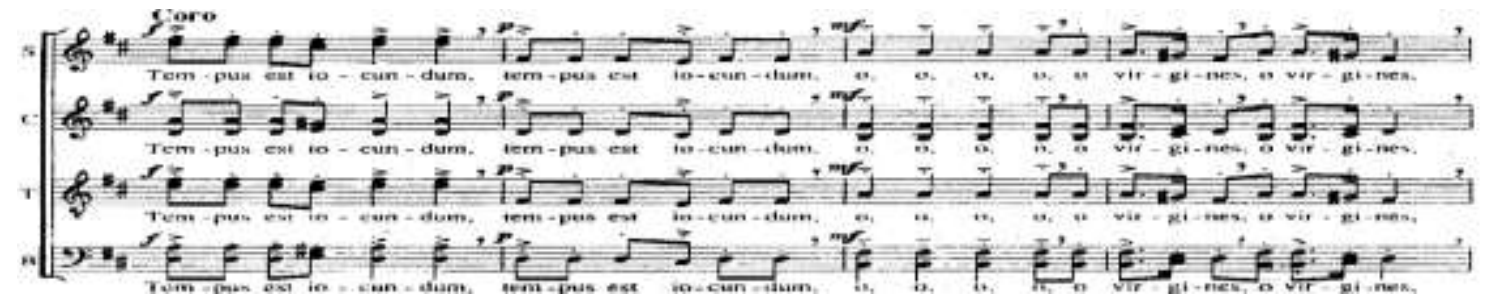

D escrição: C oro - T empus est iocundum.

Fonte: Carmina Burana, C arl O rff E D 2877 p. 105.

D epois o barítono solo responde com uma frase, e se iniciam as vozes femininas fazendo a mesma estrutura do coro do início do movimento, porém, com outro texto, e depois, a soprano solo mais o coro ragazzi respondem (na oitava adequada) com a mesma frase do barítono solo; e começam com as vozes masculinas, fazendo a mesma estrutura do coro do início do movimento, porém com outro texto, e o barítono solo responde com a mesma frase resposta; novamente vozes femininas e resposta da soprano solo e coro ragazzi, e depois todas as vozes cantam tudo inclusive a frase resposta junto com todos os solistas e coro ragazzi:

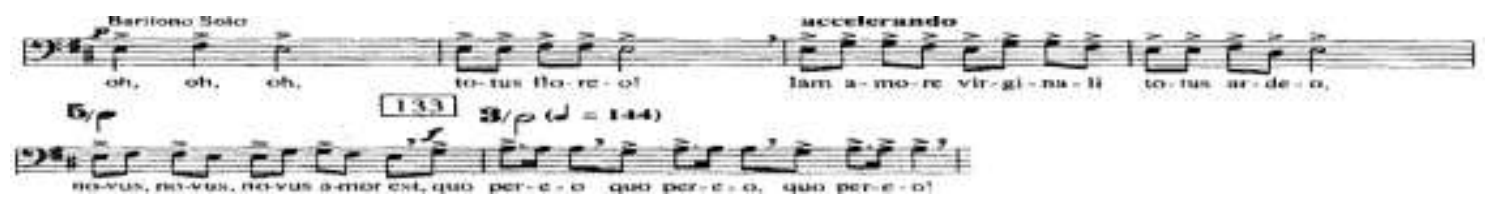

D escrição: F rase R esposta (B arítono) - T empus est iocundum.

Fonte: C armina Burana, C arl O rff ED 2877 p. 105.

0 ritmo com o coro variando em 4/4 e 3/4, e entra o barítono solo, e mantém 3/4, e no compasso que entra o coro vai para $5 / 4$ e volta a variar $4 / 4$ e 3/4, e repete toda a estrutura, pois só vai variar as vozes que cantam.

Duldissimeum é para soprano solo em 3/2, na tonalidade de Ré M aior, mas ele termina suspendendo a fim de ir para a subdominante na próxima música. É uma música directa e neumática com prevalência melismática, se desenvolvendo com predominância em graus conjuntos:

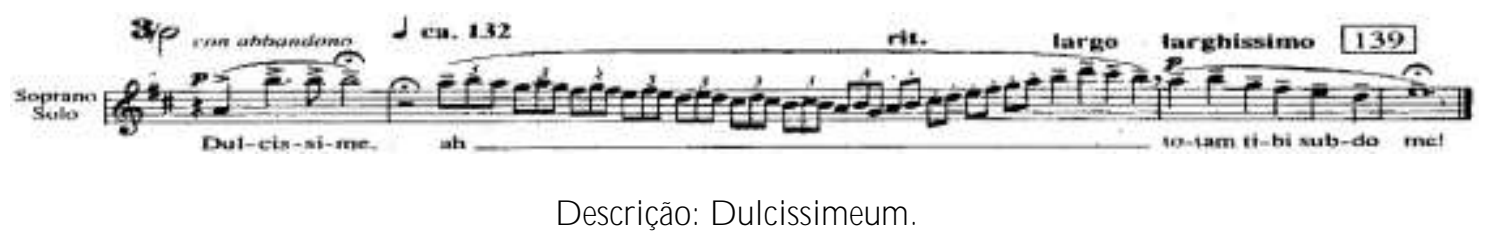

Fonte: C armina Burana, C arl O rff ED 2877 p. 115. 
Ave formosissima tem a tonalidade de Sol M aior, directa e silábica, com seis vozes (baixo, barítono, tenor, contralto, mezzo e soprano) com três linhas melódicas, todas dependentes ritmicamente, e contralto duplicando o baixo, mezzo o barítono, soprano 0 tenor:

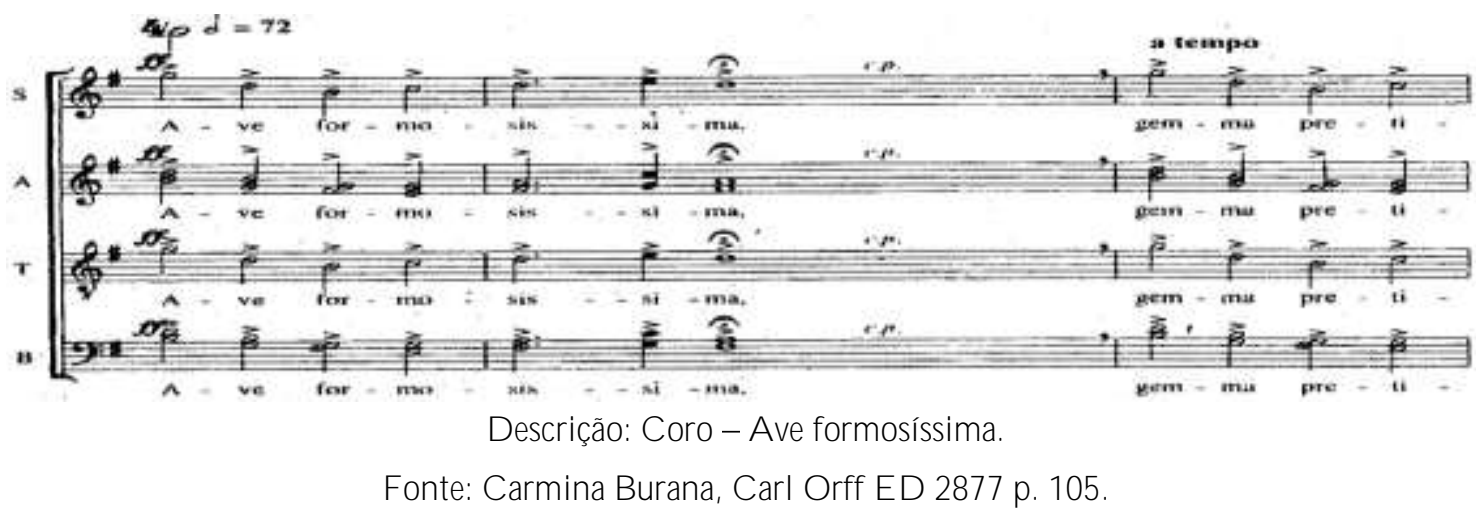

A fórmula de compasso em 4/2 só muda nas duas últimas frases, ambas com dois compassos cada, a primeira frase é em 6/2 e a última frase tem um compasso em $4 / 2$ e outro em $6 / 2$.

Para finalizar essa grandiosa obra de $\mathrm{C}$ arl $\mathrm{O}$ rff repete o movimento $0 \mathrm{~F}$ ortuna.

\section{Considerações Finais}

U ma vez que a música é uma linguagem universal do ser humano, é de grande valia a reunião de conhecimentos sobre essa arte dentro de um único trabalho. Com isso, a cultura e a sociedade ganham novos valores, pois, músicos e estudantes de música podem conhecer novos aspectos da obra.

O compositor Carl Orff escreveu a obra Carmina Burana no período da A lemanha nazista, com objetivo de, em pleno século $X X$, se servir de ferramentas da I dade M édia.

E le compôs cantos gregorianos de uma maneira que se encaixava em um cenário de extremos. Porém, se for feita uma análise minuciosa, a obra de Carl O rff possui fragmentos que não são da Idade M édia, o que não impede de remetê-la ao período medieval quando o texto de Carmina Burana foi escrito. A I dade M édia está presente dentro de Carmina Burana, além dos textos, também na parte musical, e por conta 
disso, essa análise foi realizada tendo como base teórica técnicas de composição da época.

E sta análise está respaldada no pensamento de vários autores que enriqueceram a proposta original de beneficiar a arte da interpretação, uma vez que dados técnicos sobre a obra auxiliam o trabalho do intérprete. Q ue este trabal ho possa contribuir com outros escritos ou executados. A obra é extremamente relevante e a música se constitui em importante patrimônio cultural.

\section{Referências}

BE N N ETT, R oy. U ma BreveH istória da M úsica. Rio de Janeiro:Zahar, 1986.

CH ED IA K, A Imir. H armonia \& I mprovisação I. São Paulo: I rmãos Vitale, 2009.

CO L A RUSSO, O svaldo. C armina Burana. O s Segredos de um dos $\mathrm{H}$ its da $\mathrm{M}$ úsica Clássica. C uritiba: G azeta do Povo, 2013.

Disponível em: <www.gazetadopovo.com.br/falando-de-musica/carmen-buranaos- segredos-de-um-dos-hits-da-musica-classica/> A cesso em: 22/11/2016.

CO PLA N D , A aron. C omo ouvir e entender música. São Paulo: R ealizações E ditora, 2011.

G A L IN D O, C leusyA raú. N azi smo A lemão eas L ės de $N$ uremberg: Sentimento de Poder ou Ó dio? G uarujá-SP: R evista Intraciência, 2013.

Disponível em:

$<w w w$. faculdadedoguaruja.edu.br/revista/edicoesA nteriores.asp >A cesso em:

22/11/2016.

GOULART, Diana. Dalcroze, Orff, Suzuki e Kodály: Semelhanças, Diferenças, E specificidades. Seminário movimentos pedagógicos I do curso de pós-graduação em E ducação M usical no Conservatório B rasileiro de M úsica, Rio D e Janeiro, 2000.

GROUT, Donald J.; PALISCA, Claude V. História da Música Odidental. L isboa:G radiva, 1994. 
JÚ N I O R, H ilário F ranco. A I dade M édia: N ascimento do 0 cidente. 2ạ. E d. São Paulo: Brasiliense, 2001.

LUKACS, John. A Ú ltima Guerra E uropéia. Rio de Janeiro: N ova F ronteira, 1980.

M E D, B ohumil. Teoría da M úsica. 4å E d. Brasília: M usimed, 1996.

O RFF, C arl. Carmina Burana. C antiones Profanae. E d 2877, Shott-E amc, 1991.

PRIO L LI, M aria L uisa de M attos. Prinápios básicos da música para a juventude 20 Volume. 19a E d. Rio de Janeiro: C asa O liveira de M úsica L T D A, 1996.

SA D IE, Stanley. Dicionário G rove de M úsica.E d C oncisa.R io de Janeiro: Jorge Z ahar E ditor, 1994. 